\title{
CHROME ORES OF SOUTHEASTERN PENNSYLVANIA AND MARYLAND.
}

\author{
By Eleanora Buiss Knopf.
}

\section{INTRODUCTION.}

Chromite occurs in numerous areas of serpentine throughout the extreme southeastern part of Pennsylvania and the eastern part of Maryland. Deposits of commercial importance lie along the Maryland-Pennsylvania State line about 4 miles east of Susquehanna River and 5 miles northeast of the small town of Rising Sun, Cecil County, Md. Another deposit that has been recently worked is in Maryland in the Soldiers Delight area of serpentine, about 15 miles northwest of Baltimore.

The topography of the Piedmont district of eastern Pennsylvania and Maryland, in which the chromite deposits are situated, is gentle and rolling. The country is well drained by numerous small streams, which offer a sufficient source of water for concentration. The climate is not rigorous. Roads are in general good, consisting of fair dirt roads within easy distance of excellent pikes. Railway transportation is within 4 or 5 miles of the mines and furnishes cheap and speedy access to the large chrome-ore markets. The State-line chrome ores are about 15 miles south of the large electric-power plant of the Pennsylvania Water Power Co. on Susquehanna River at Holtwood, $\mathrm{Pa}$.

In November, 1917, I made a brief examination of the chromebearing rocks of the "State-line serpentine" belt of Pennsylvania and Maryland and of the Soldiers Delight deposit in Maryland. At that time no mines were in operation in the State-line chrome ores. I am indebted to Mr. J. H. Buxton, general manager of the Maryland Chrome Co.'s mine at Soldiers Delight, for his courtesy at the time of my visit.

The map that accompanies this report (fig. 24) shows the general occurrence of the chrome-bearing serpentine areas in Pennsylvania and Maryland. The outline of the serpentine belt in southern Pennsylvania, as shown on this map, was determined by me during a 
four days' hasty reconnaissance trip in that region and is to be regarded as only approximate. The areal distribution of the serpentine in Cecil County and Harford County, Md., is taken from geologic maps of those counties published by the Maryland Geological Survey.

\section{HISTORICAL SKETCH.}

In 1827 Isaac Tyson, of Baltimore, noticed some black boulders supporting a cider barrel on the floor of a farmer's cart in the Belair market. His familiarity with European literature had already led him to recognize the occurrence of chromite at Bare Hills, 6 miles

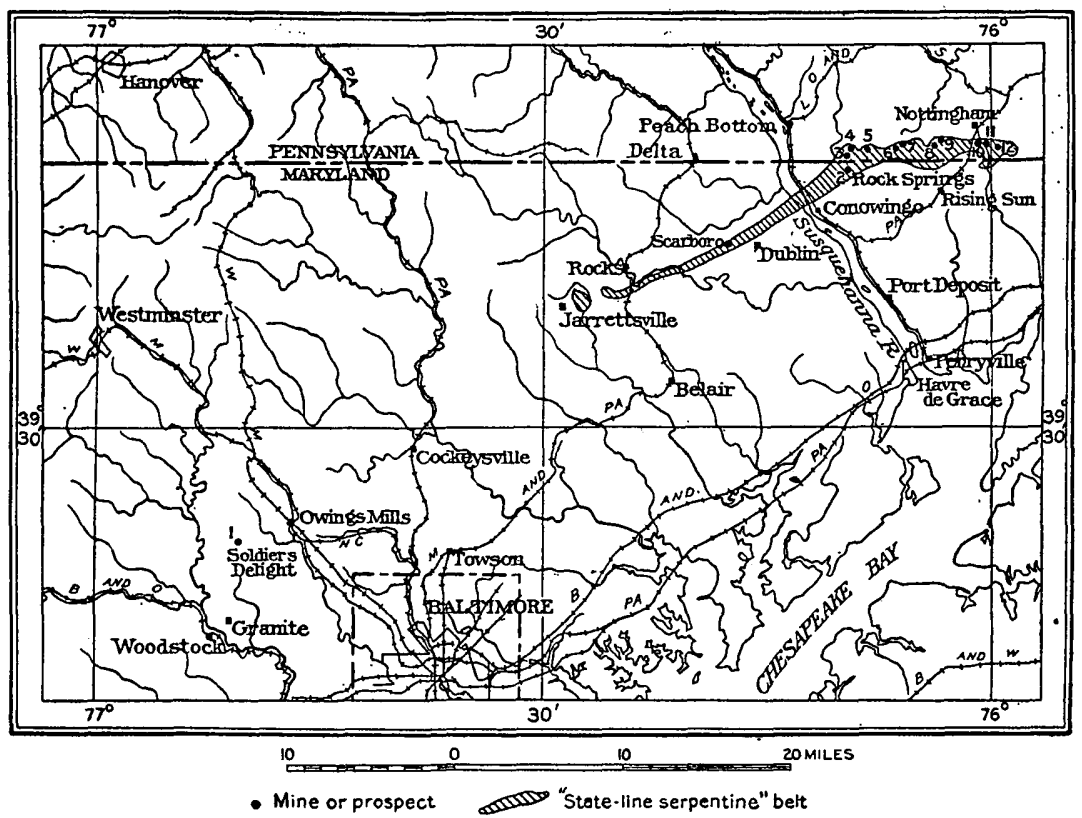

Figure 24.-Map of chrome-bearing areas in Maryland and Pennsylvania. Numbers refer to descriptions in text, pages $95-98$.

north of Baltimore, and he readily identified the heavy boulders in the farm wagon as chrome ore. Upon inquiry he traced their origin to a locality near Jarrettsville, in Harford County, which afterward became the site of the Reed mine. In this mine chromite formed several lenses, the largest of which was 80 feet long, 25 feet wide, and 4 to 8 feet thick. ${ }^{1}$ It is said that the total output was about 100,000 tons. $^{2}$

Tyson had noticed that chromite is associated with serpentine, and by further prospecting, conducted chiefly during his search for sources of magnesite, he found many deposits of chromite in the serpentine belt of Maryland and Pennsylvania. His most important

1 Glenn, William, Am. Inst. Min. Eng. Trans., vol. 25, 1895.

Day, D. T., U. S. Geol. Survey Mineral Resources, 1883-84, p. 568, 1885. 
discovery proved to be that of the deposit worked at the Wood mine, which is in Little Britain Township, in Lancaster County, Pa., on a hill almost surrounded by a horseshoe bend of Octoraro Creek. This mine, which was at one time the largest source of chromium in the world, was worked from 1827 until 1882, except during 1868 to 1873 , when it was flooded. Three other mines near Rock Springs, Md., known as the Line pit, the Peebles mine, and the Jenkins or Rock Springs pit, were worked with more or less success for several years but were all abandoned by $18700^{3}$ From 1873 to 1882 the Wood mine was the only operating chrome mine in the eastern United States. Throughout the areas of chrome-bearing serpentine in Maryland and Pennsylvania the washing of chrome sand has continued to be a small and intermittent industry up to the present time.

From 1828 until about 1860 the chromite ores of Pennsylvania and Maryland were practically the only sources of supply for the world. All the chrome mines of the United States were controlled by the Tyson Mining Co., of Baltimore, Md. This company held the monopoly on production until about 1895 .

At the time of the Civil War Turkish ores had begun to come into the United States at prices so low that the control of chromite supplies for the world's market was transferred from the eastern United States to Turkey and Asia Minor, where it remained until about 1905, when the production of Turkish ore decreased owing to the strong competition of New Caledonian deposits. After the Civil War the Wood mine, which before 1868 was reported to have produced as much as 400 to 500 tons a month, reduced its output to 400 or 500 tons a year. In the meantime California chrome ores that had been discovered in 1869 and put on the market about 1878 were furnishing from 1,500 to 2,000 tons a year. In 1882 operations ceased at the Wood mine, which for several years had been held as a source of reserve stock to offset uncertainties of long shipments from the Pacific coast. Since the closing of the Wood mine the chrome industry in the eastern United States has lain dormant. One or two unsuccessful attempts have been made to renew activities, notably in 1897, when mining was revived in Chester County, $\mathrm{Pa}$., by washing stream chrome. The production was small, however, and these operations lasted only for about three years. During this time activity had completely ceased in the California region owing to the competition of imported ore.

It is the opinion of old chrome miners in southern Pennsylvania that the eastern mines were closed because of the decline in price rather than because of exhaustion of the ore. At several mines failure to operate seems to have resulted from litigation and con-

${ }^{3}$ Pennsylvania Second Geol. Survey Rept. C3, pp. 177, 178, 1880. 
tention over mining rights when drifts were extended under adjoining properties.

After the United States entered the recent war the demand for chrome ore, which. had increased from 66,000 tons in 1913 to about 163,000 tons in 1916, became still greater. The domestic production of chromite had to be greatly increased owing to the urgent necessity for the release of the shipping that had been employed in bringing large imports of chromite from New Caledonia to the United States. The imports of Rhodesian ore had already ceased, owing to the lack of transportation facilities in Rhodesia by which the ore might be carried from the mines to the port of shipment. Various attempts were made to revive the eastern chrome industry, and in $1917 \mathrm{~J}$. Lynwood Garrison acquired the mineral rights on the old Line pit and on the Rock Springs or Jenkins pit. The Line pit has been operated by the Chrome Mining Co., which has unwatered the mine to a depth of more than 200 feet, located one ore body, and engaged in exploratory work.

\section{GEOLOGY OF THE ORE DEPOSITS.}

Chromite is restricted in its geologic occurrence to the ultrabasic peridotites and pyroxenites and their serpentine derivatives. The chrome-bearing serpentine of Maryland and Pennsylvania occurs in a belt that extends along a northeasterly strike from Soldiers Delight in Maryland to the southwest corner of Chester County, Pa. This serpentine represents the most ferromagnesian portion of a group of igneous rocks that are well exposed along Susquehanna River from Perryville northwest. The most siliceous portion is the so-called "Port Deposit granite," north of Perryville, which has the chemical and mineral composition of a quartz monzonite. The northwest boundary of the quartz monzonite is a band about 2 miles wide of quartzite and mica schist into which the quartz monzonite has been intruded. This band of highly metamorphosed sediments is succeeded northwestward by quartz-mica-hornblende diorite, which in turn is succeeded by quartz diorite, and this by a gabbro and norite intrusion that passes on its northwest border into a highly magnesian differentiate represented by a pyroxenite and peridotite mass almost completely altered to serpentine. The so-called "State-line serpentine" belt of southern Pennsylvania appears in more or less continuous lenticular areas as far southwest as Jarrettsville, Md. From the neighborhood of Scarboro to Jarrettsville the serpentine is surrounded by foliated crystalline rocks that are probably the metamorphosed equivalents of sandstones and argillites of Lower Cambrian or pre-Cambrian age. Between Jarrettsville and Soldiers Delight for a distance of about 25 miles serpentine outcrops are lacking. 
Until more detailed petrologic work is done upon the igneous rocks of Cecil, Harford, and Baltimore counties it is impossible to state with certainty the relations of the several igneous types. It would appear probable that the gabbro and norite that extend in a band from a locality near Elk Creek, about 10 miles northeast-of Newark, Del., to Laurel, Md., represent a sill or laccolith intruded under a cover of sediments that have been subsequently removed by erosion.

The prevailing dip of the crystalline schists in this region is southeast, and the contact between the serpentine and the crystalline schists on the northwest border of the intrusion also dips southeast. The strike of the serpentine belt parallels the general strike of the country rock. It seems probable that the serpentinized peridotite-pyroxenite series represents a floor phase of the intrusion, derived from the gabbro magma by a gravity differentiation of the ultrafemic constituents in a manner analogous to the formation of the celebrated sheet at Sudbury, Ontario. Within the serpentine area between Scarboro and Dublin, in Harford County, associated with a lens of talc, there is an area of zoisite-actinolite schist that probably represents a gabbro in which the feldspar has been altered to zoisite. The fact that bodies of metagabbro and metadiorite are so intimately associated with the serpentine that it is impossible to separate them in the field would tend to confirm the idea that the rock from which the serpentine originated was a differentiate from the gabbro.

\section{THE ORES.}

\section{PHYSICAI CHARACTER.}

The chrome ore of Maryland and Pennsylvania occurs in three ways-as massive compact chromite in nodules and pockets of variable size in a serpentine gangue; as a disseminated ore in which the grains of chromite are rather evenly distributed through the serpentine; and as placer deposits.

The massive ore is composed of a dense, brilliantly lustrous aggregate of chromite. It is filled with fractures, in which has been deposited a white or green fibrous serpentine. These cracks are doubtless due to stress developed by the increase in volume attendant upon serpentinization of the rock mass. The fact that the fractures are in some places faulted, with a deformation of the interstitial filling, shows that there has been a relief of a stress along previously existing planes of weakness. These planes of movement commonly show slickensided serpentine and a coating of white magnesian carbonate. Various rare minerals are developed at the Wood mine in connection with chromite, such as brucite, deweylite, hydromagnesite, and williamsite. Massive ore is not of very common occurrence, hav- 
ing been found chiefly at the Wood mine, the Line pit, and Soldiers Delight.

The disseminated ore known among the chrome miners of the region as "birdseye" consists of rounded grains of chromite scattered more or less irregularly throughout a matrix of white or yellow to blue-green serpentine that in places shows rounded grains of original olivine. The degree of concentration of the chromite exhibits all stages, from lenses in which chromite forms an almost pure aggregate through an evenly spotted rock containing stringers of chromite to a serpentine in which the isolated and minute chromite crystals may be regarded as accessory. Ore bodies are extremely irregular in shape and variable in size. The ore usually occurs in more or less lenticular pockets that range from 1 foot to 10 feet in length and are about 4 feet wide. The ore body of the Wood mine was evidently exceptional in character. It occurred in what has been described as a well-defined vein with distinct footwall and hanging wall. The vein persisted for about 300 feet with an average width of 20 feet. Vertical or horizontal offshoots from this vein extended at intervals into the footwall.4

Erosion of chromiferous serpentine causes a simple natural concentration of the heavy chromite and magnetite of the rock. At some places in the chrome-bearing district the streams carry workable deposits of black sand. Profitable extraction depends upon the ratio of chromite to magnetite in the sand and upon the content of chromic oxide in the chromite. Several deposits near the Maryland-Pennsylvania State line have been worked with minor success. Chrome sand was reported to occur at the Wood mine, ${ }^{5}$ but no confirmation of this report could be obtained from former chrome miners in the region. A good-sized deposit of chrome sand occurs on the Line pit property in Maryland. Black Run, about half a mile west of the old Scott mine, was reported as a former source of chrome sand, and in 1918 preparations were being made to wash chrome sand there.

\section{COIIPOSITION OF THE ORE.}

The Pennsylvania ore is of good quality and is superior in grade to the California ores. Several analyses show a content of chromic oxide in the chromite of Pennsylvania that ranges from 48 to 63 per cent, while the California ores contain about 40 to 45 per cent. The Pennsylvania chromite compares favorably with the ores of Turkey and Asia Minor and also with those of New Caledonia and Rhodesia.

The massive ore of the Wood mine was reported to assay as high as 56.5 per cent of chromic oxide and to average 48 per cent. ${ }^{6}$ Ore

4 Frazer, Persifor, Pennsylvania Second Geol. Survey Rept. C 3 , p. 192, 1880.

I Idem, p. 195.

Idem. 
from the Line pit runs about 50 per cent of chromic oxide, and the ore from Soldiers Delight runs from 40 to 50 per cent.

The chromic oxide in the spotted ore from the Line pit averages about 30 per cent. Analyses of average samples of disseminated ore from dumps on the Scott mine property near Nottingham showed 33.27 to 34.27 per cent by weight of chromite in the ore. An analysis of the chromite recovered by concentration from the sample showed 48.79 per cent of alumina and iron oxide and 51.21 per cent of chromic oxide.

Chrome sand from Black Branch Run, a mile southeast of the Wood mine, was reported to contain 38 per cent of chromic oxide. At the Wood mine the stream chrome ore contained about 46 per cent of chromic oxide. ${ }^{7}$ Chrome sand from a stream about a mile west of Rock Springs, Md., on the Line pit property, runs about 40 per cent of chromic oxide, and chrome sand from the Soldiers Delight property near Baltimore runs from about 28 per cent to about 43 per cent. ${ }^{8}$

\section{POSSIBIIITIES OF CONCENTRATION.}

In the prosperous days of the eastern chrome industry disseminated ore was not considered sufficiently valuable to repay the cost of concentration, because there was a large supply of massive ore that could easily be cobbed and hand sorted and that was of sufficiently good quality to meet the demands of that period. At the time of the shortage of chrome ore in the United States during the war the question whether low-grade ores can be profitably concentrated assumed new importance.

In the consideration of the possibility of profitable concentration the chemical composition of the ore is a matter of significance. It is an obvious fact, but one that has nevertheless sometimes been overlooked, that if the chromite molecule in a disseminated ore carries less than 30 per cent of chromic oxide excellence of recovery can not possibly produce a high-grade concentrate. Omission to determine the chromic oxide content of chrome sand has frequently caused failure of sand-washing operations-as in the case of the chrome wash near Rising Sun, where the chromic oxide content of the molecule was less than 5 per cent. ${ }^{\circ}$ Less obvious perhaps is the fact recently noted by Singewald,,$^{10}$ that the magnetism of the spinel molecule is dependent upon the ratio of alumina to chromic oxide. Therefore in a magnetic black spinel that would be taken for magnetite in prospecting, the composition of the trivalent oxide might be largely $\mathrm{Cr}_{2} \mathrm{O}_{3}$ with a very small amount of $\mathrm{Al}_{2} \mathrm{O}_{3}$.

\footnotetext{
7 Frazer, Persifor, op. cit.

8 Singewald, J. T., Econ. Geology, vol. 14, p. 195, 1919.

Idem.

${ }^{10}$ Idem, p. 197.
} 
Still another factor that becomes significant in the case of chrome ore to be used in the manufacture of ferrochrome is the ratio of chromium to iron in the chromite molecule. In making ferrochrome ${ }^{11}$ the iron lost in the slag averages about 8 per cent of the $\mathrm{FeO}$ in the charge, corresponding to a loss of about 6 per cent of iron. The loss of chromium ranges from 30 per cent in making a ferrochrome that contains 8 per cent of carbon to 5 per cent in making a ferrochrome that contains' 6 per cent of carbon. It can be shown from the above figures that the loss of chromium is five times as great as the loss of iron, and therefore in producing a ferrochrome containing 6 per cent of carbon it is necessary to use a chrome ore containing at least twice as much chromium as iron in order to produce a ferrochrome containing 60 per cent of chromium.

The following table shows that chromite containing 50 per cent of chromic oxide and 25 per cent of ferrous oxide can not be used to produce a ferrochrome with 60 per cent of chromium and 6 per cent of carbon:

\begin{tabular}{|c|c|}
\hline mite charge & \\
\hline Chromic oxide in ore & 50 \\
\hline Chromium content & 34 \\
\hline Ferrous oxide in ore & 25 \\
\hline Iron content_- & 19. 4 \\
\hline Chromium in charge_-_- & 680 \\
\hline Iron in charge & 388 \\
\hline Ferrochrome containing 8 per cent of carbon: & \\
\hline Chromium recovered (loss in slag, 5 per cent) & 646 \\
\hline Iron recovered (loss in slag, 6 per cent) & 365 \\
\hline Chromium content of ferrochrome & 65 \\
\hline $\begin{array}{l}\text { Ferrochrome containing } 6 \text { per cent of carbon: } \\
\text { Chromium recovered (loss in slag, } 30 \text { per cent) }\end{array}$ & \\
\hline $\begin{array}{l}\text { Iron recovered (loss in slag, } 6 \text { per cent) } \\
\text { Chromium content of ferrochrome }\end{array}$ & $\begin{array}{l}365 \\
56.6\end{array}$ \\
\hline
\end{tabular}

In this connection it is interesting to note the fact that absolutely pure chromite would not be suitable for use in the manufacture of ferrochrome containing 60 per cent of chromium, as the theoretical molecule of chromite contains 68 per cent $\mathrm{Cr}_{2} \mathrm{O}_{3}$ and 32 per cent $\mathrm{FeO}$, which is equivalent to 46.5 per cent of chromium and 24.6 per cent of iron. As a matter of fact, the high ratio of chromium to iron in certain chrome ores is caused by the replacement of a certain amount of the ferrous iron oxide by magnesia. The following table shows the relative percentages of iron and chromium in several domestic ores from California and Oregon as contrasted with. ore from New Caledonia, Turkey, and Cuba.

a Keeney, R. M.; Am. Inst. Min. Eng. Trans., Colorado meeting, Sept., 1918, p. 3125. 
Analyses of chrome ore. ${ }^{a}$

\begin{tabular}{|c|c|c|c|c|c|c|}
\hline & Califo & and 0 & on. & Turkey. & New Cal- & Cuba. \\
\hline 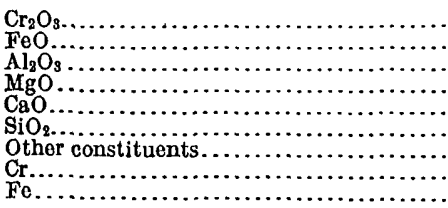 & $\begin{array}{r}51.40 \\
16.71 \\
17.26 \\
6.60 \\
\text { Trace. } \\
4.26 \\
.13 \\
35.16 \\
12.98\end{array}$ & $\begin{array}{r}42.25 \\
13.37 \\
13.40 \\
13.02 \\
1.00 \\
8.84 \\
28.11 \\
10.39\end{array}$ & $\begin{array}{r}41.91 \\
15.42 \\
16.60 \\
12.82 \\
8.70 \\
8.07 \\
28.67 \\
11.87\end{array}$ & $\begin{array}{l}51.7 \\
14.2 \\
14.1 \\
14.3 \\
1.7 \\
3.5 \\
.3 \\
35.36 \\
11.03\end{array}$ & $\begin{array}{r}55.7 \\
13.2 \\
16.2 \\
9.8 \\
.25 \\
.2 \\
1.30 \\
38.10 \\
10.26\end{array}$ & $\begin{array}{r}50.00 \\
18.57 \\
12.44 \\
13.38 \\
2.16 \\
3.82 \\
1.14 \\
34.20 \\
14.43\end{array}$ \\
\hline
\end{tabular}

- $a$ California and Oregon analyses were taken from Keeney, R. M., Manufacturo of ferroalloys in the electric furnace: Am. Inst. Min. Eng. Trans., Colorado meeting, September, 1918, p. 1334. Foreign analyses were taken from Lyon, D. A., Keeney, R. M., and Cullen, J. F., The electric furnace in metallurgical work: Bur. Mines Bull. 77, p. 135, 1916.

Profit in concentration is largely dependent upon the price of concentrates. Since the price of chrome ore has fallen the concentration of eastern chromite is not so likely to be financially successful as it might have been during the war. Nevertheless, as long as the market for chrome ore remains in the East the high freight tariff on chrome ore hauled from the Pacific coast will offset to some extent the high cost of labor and material incident to milling operations in the East.

\section{ORIGIN OF THE ORES.}

It is generally conceded that the chromite grains that are widely disseminated throughout many highly magnesian rocks are a product of early crystallization from the magma. The presence of chromite inclusions within olivine crystals indicates that the chromite was the earliest constituent in the magma to crystallize.

Diller ${ }^{12}$ has recently shown in his studies of western ores that chromite is probably one of the earliest magmatic constituents to crystallize. He finds that the silicate minerals begin to crystallize after the solidification of the earliest chromite and continue after the chromite has finished crystallizing. This order of crystallization is indicated by the presence of many peripheral inclusions of silicate minerals in grains of chromite that contain no inclusions in their cores. The chromite has crystallized more rapidly than the silicates, so that while it includes in its outer zone some of the early formed silicate minerals it is inclosed by a groundmass of silicates.

It is a more or less disputed question whether the irregularly distributed lenses of chromite that form ore bodies are entirely due to early magmatic segregation or whether they represent a later phase of differentiation.

The chrome ores of the "State-line serpentine" belt of Maryland and Pennsylvania confirm, by their manner of occurrence, the idea that chrome ores are a product of a gravity differentiation caused by

12 Diller, J. S., Am. Inst. Min. Eng. Bull. 153, p. 2018, Sept., 1919. 
sinking of the earliest formed crystals. The fact that the ore bodies occur in irregular bunches suggests the differentiation of chromite in the "schlieren" that are common in igneous rocks. Even where the ore is said to occur in a vein, as at the Wood mine, it is probable that chromite really formed in a veinlike segregation. The chrome deposits lie along the northwest border of the serpentine, and the ore bodies dip southeast, following the dip of the including sill. Thus they appear to be localized along the floor of the sill. In this respect they recall the occurrence of the Sudbury nickel ores, which are segregated around the bottom rim of a spoon-shaped laccolith.

Two thin sections of disseminated ore from the neighborhood of Nottingham, Chester County, Pa., were studied in order to determine the order of crystallization of the chromite and silicates, but the evidence furnished by these slides could not be considered conclusive. In one the original rock is seen to be a dunite; in the other the original silicate has been completely serpentinized. A peripheral concentration of silicate inclusions can be recognized in one crystal of chromite, but in general the inclusions are very evenly scattered throughout the crystals. Some chromite grains are entirely free from inclusions. The chromite has been fractured by a system of cracks that are filled with serpentine, indicating that these cracks were formed during the increase in volume of the rock mass produced by serpentinization. Whether or not the chromite was the first constituent to crystallize, it did crystallize before the formation of the serpentine. Therefore if the serpentine, as suggested by Weinschenk, ${ }^{13}$ Merrill, ${ }^{14}$ Smith, ${ }^{15}$ Benson, ${ }^{16}$ and others, is a product of hydrothermal metamorphism, the crystallization of the chromite antedates the hydrothermal action and can not be ascribed to late magmatic crystallization under the influence of mineralizers as suggested by Tolman and Rogers. ${ }^{17}$

In connection with the origin of the serpentine it is interesting to note the frequent occurrence of magnesite at many places throughout the "State-line serpentine" belt and also the presence within the serpentine area of a considerable quantity of vein quartz. Near Flintville, on the west side of Susquehanna River, in Harford County, Md., the vein quartz is so abundant that it is quarried for use in making porcelain. It is more than possible that the thermal waters that were derived from the peridotite magma caused both the serpentinization of the peridotite and the subsequent carbonation of the magnesian rocks, together with the deposition of quartz in fissures.

${ }^{13}$ Weinschenk, E., Neues Jahrb., 1895, Band 1, p. 226.

14 Merrill, G. P., Geol. Mag., dec. 4, vol. 6, p. 354, 1899.

${ }^{16}$ Smith, G. O., U. S. Geol. Survey Geol. Atlas, Mount Stuart folio (No. 106), 1904.

${ }^{16}$ Benson, W. N., Am. Jour. Sci., 4th ser., vol. 46, p. 727, 1918.

${ }^{17}$ Tolman, C. F., and Rogers, A. F., A study of the magmatic sulfld ores: Leland Stanford Junior Univ. Pub. 26, p. 64, 1916. 
Another significant feature of the geology of the region is the occurrence of soda pegmatites within the "State-line serpentines." They are quartz-free rocks, composed chiefly of albite and hornblende. These are the only true soda pegmatites in the United States, and their occurrence is confined to the altered peridotites and pyroxenites. ${ }^{18}$ Benson ${ }^{19}$ cites the common occurrence of albitic veins in peridotite as an evidence of the expulsion of sodic vapors from the peridotitic magma. More detailed petrologic work would be necessary in order to establish conclusive evidence upon the origin of the chrome-bearing serpentine and upon the manner of formation of the chromite. This brief study of the region indicates at least the possibility that the chromite is a product of early magmatic differentiation from a highly magnesian peridotite magma and that the serpentinization of the peridotite has been effected to a large degree by the action of siliceous carbonated waters derived from a later differentiation of the original magma.

The possibility that the Maryland-Pennsylvania chrome ores may have been localized by gravity differentiation along the bottom of a sill or laccolith is significant from the prospector's point of view, for it indicates the probability that ore may continue to be found at intervals along the northern border of the southward-dipping serpentine. However, the pockets that contain the massive ore are so irregularly distributed that discovery of chrome ore will continue to be largely a matter of chance.

\section{MINES AND PROSPECTS.}

During 1917-18 I examined one operating mine and eleven abandoned mines and prospects in Maryland and Pennsylvania. They are indicated by numbers on figure 24 and in the following descriptions. The isolated occurrences of chromite that have been worked to a small extent in Delaware County, $\mathrm{Pa}$., were not visited at the time of this examination.

\section{SOLDIERS DELIGHT DISTRICT.}

The chrome-ore district at Soldiers Delight, Md. (1), about 15 miles northwest of Baltimore, is one of the old claims of the Tyson Mining Co. It has been an intermittent source of chrome ore for a number of years and since March 1, 1918, has been under development by the Maryland Chrome Corporation. The shipping point for the ore, about 4 miles east of the mine, is Owings Mills, on the Harrisburg division of the Western Maryland Railway.

Some chrome has been washed at intervals for years on the farms of Jay Gore, R. A. Triplet, and J. A. Dolfield. The washing is car-

${ }^{29}$ Benson, W. N., Linnean Soc. New South Wales Proc., vol. 38, p. 612, 1913. 
ried on in a rather crude instrument known as a buddle. It is a long, narrow trough with a gently inclined slope. The water, impounded by a dam in the small stream where the washer is operated, is run into the trough over an inclined partition that cuts off a small portion of the head of the buddle. The operation is well described by Singewald. ${ }^{20}$ The resulting concentrate brings a high price because it is especially well adapted for use in setting colors on porcelain. The average annual output of about 25 tons is shipped to Europe. ${ }^{21}$

The old Shote mine on the Soldiers Delight property was operated during the war by the Maryland Chrome Corporation. A shaft was sunk for 200 feet and a drift opened along the lens for 160 feet. The granular ore occurred in seams 1 to 2 inches in width, disseminated in a green serpentine. In places the chromite is concentrated into lenses that range from 18 inches to 4 feet in width. The pockets are extremely irregular and pinch out and swell again within a distance of a few inches. The material that came from the mines was screened through a 40 -mesh screen, and all ore that averaged over 40 per cent of chromite was picked out from the coarser material by hand and shipped. It was planned to crush the lean ore in a disk mill and to concentrate it on tables, but the end of the war put a stop to milling operations.

\section{CHROME MINING CO.'S CLAIMS.}

The Line pit (2) is three-quarters of a mile northwest of Rock Springs, Md., on the Maryland-Pennsylvania State line. There are two openings there called by Frazer ${ }^{22}$ the Line pit and the Lowe pit.

The Lowe pit was originally opened by Andrew Lowe and Benjamin Gibson, who obtained a large quantity of chrome. The Maryland part was acquired by the Tysons, who were probably the ones to open the Line pit. The ore in the Line pit was massive and ran over 50 per cent of chromic oxide. It was mined by a shaft that was sunk to a vertical depth of about 92 feet; a drift ran south from the shaft for 75 feet, and another shaft was sunk from the drift on a $75^{\circ}$ grade for 106 feet. In 1917 the Chrome Mining Co. acquired the mineral rights on the property, unwatered the shaft, sank 40 feet below the old level, and struck a lens of massive ore about 10 feet long by 4 feet wide that averaged 50 per cent of chromic oxide. There is also estimated to be several thousand tons of chrome sand available in the stream south of the Line pit.

The Jenkins pit (3) is in Pennsylvania, about five-eighths of a mile northeast of the Line pit. The ore is granular and probably

${ }^{20}$ Singewald, J. T., Econ. Geology, vol. 14, pp. 191-192, 1919.

${ }^{2 t}$ Idem.

22 Frazer, Persifor, Pennsylvania Second Geol. Survey Rept. C3, p. 177, 1880. 
runs about 35 per cent chromite. The Rock Springs pit (4), about 300 yards northeast of the Jenkins pit, also showed disseminated ore. Both mines were acquired by the Chrome Mining Co., with a view to concentrating the ore.

The Tyson-Reynolds pit (5) also contained disseminated ore but was never worked to any extent.

\section{WOOD MINE.}

The Wood mine (6) is in Lancaster County, $\mathrm{Pa}$., about 5 miles northwest of Rising Sun, Md. It contained the largest single body of chrome ore ever known, and for some years during the early prosperous days of the Pennsylvania chrome industry it furnished practically the entire world's supply of chrome ore. When the mine was closed in 1881 the total output was estimated at 100,000 tons. In its present state the mine consists of two openings. The larger opening is about 90 by 50 feet and trends northeast. It leads into a shaft that dips southward. About 150 feet south of this large pit is a smaller opening leading into a shaft that is connected by a northward drift with the larger opening. The greatest depth attained was 720 feet. ${ }^{23}$ During the last few years of the mine's activity it was worked only through the larger opening down to a level of about 244 feet. The water level was kept constant by a pump operated through the deep shaft. Contrary to the usual condition in chromite deposits, the ore occurred in a vein along a well-defined footwall. The vein was about $300^{\circ}$ feet long and had an average width of 20 feet. Large dumps containing thousands of tons of waste surround the mine, but the ore, which was massive, has been well sorted out. It was cobbed when labor was plentiful. Sometimes it was crushed and concentrated on jigs, and the residue was washed in a buddle.

TEXAS MINE.

Another small mine (7) on the Wood property was tentatively worked some years ago by the Texas Mining \& Manufacturing Co., of New York. On account of the low price of ore and scarcity of labor the company allowed its rights to lapse after taking out about 40 tons. The chromite occurs in massive and disseminated ore, but the percentage of chromite in the disseminated ore on the dumps is not very high.

\section{NOTTINGHAM MINES.}

Near Nottingham, Chester County, Pa., there is a series of three abandoned mines known as the Scott (9), the Moro Philips (10), and the Stence (11), where there appears to be a concentrating ore of fair grade. Estimates of the quantity of ore available are difficult to

${ }^{23}$ Frazer, Persifor, Pennsylvania Second Geol. Survey Rept. C3, p. 192, 1880. 
make, owing to the lack of other than surface indications, but the facts that at one mine about 2,000 tons of disseminated ore was lying on the dumps in 1917 and that rock taken a few feet below the surface abejt a mile and a half east of the mine contains disseminated ore of the same character indicate that a considerable quantity of similar ore may lie below the surface. When the examination was made material from the large dumps was being employed as road metal, a fact that shows that the presence of possibly valuable chromite in the rock had been disregarded up to that time.

The Scott mine was worked by the Tyson Mining Co. to a depth of 200 to 250 feet. The reports of the depth of the Philips mine were extremely conflicting, but it was probably worked to a depth of more than 300 feet. Old miners say that the mine contained a great deal of water.

\section{HILAMAN MINE.}

The Hilaman mine (12) is $1 \frac{1}{2}$ miles southeast of Nottingham. The Electro-Metallurgical Co. acquired the mining rights on this property and the concentration rights on Northeast Stream. Chromite occurs in a disseminated ore of fair grade similar in character to the ore from the Scott and Moro Philips mines.

\section{KIRK MINE.}

A pit (8) about 45 feet deep. south of Black Run and about $2 \frac{1}{2}$ miles southwest of Nottingham, owned by Edward Kirk, of Oxford, $\mathrm{Pa}$., was being unwatered by horsepower in 1918. The ore on the old dumps was both massive and disseminated.

\section{SUMMARY.}

Chrome ore was discovered in Maryland as early as 1827. Until 1860 Maryland and Pennsylvania furnished the world's supply of chrome ore, but in 1860 the chief source of the world's supply was transferred to Turkey. Since 1882 practically all of the output of chrome ore in the United States has come from the Pacific coast, and the industry in the Eastern States has lain dormant. Under the stimulus to production caused by war necessities attempts have been made to revive the production of Maryland and Pennsylvania mines. Two mines were reopened, and preparations were made to concentrate the disseminated ores.

The chromite is found in rock ore and in alluvial sand. The rock ore is both massive and granular. It occurs in serpentinized pyroxenites and peridotites that probably represent ultrafemic differentiates of a gabbro intrusion. The massive ore occurs in pockets of variable size. Ore bodies already discovered are usually about 
1 to 10 feet long and 4 feet wide. The ore body of the Wood mine was exceptionally large-about 300 feet long and 20 feet wide. The ore is of good quality, and its chromic oxide content, 48 to 63 per cent, is higher than that of the California ores. The ore occurs at intervals in a belt 50 miles long that extends from the southwest corner of Chester County, Pa., to the neighborhood of Baltimore, Md. It has probably originated by the sinking of chromite grains during the crystallization of a highly magnesian magma. 



\title{
DEPOSITS OF CHROME ORE IN NORTH CAROLINA.
}

\author{
By J. Volney Lewis.
}

ABSTRACT OF REPORT.

The chrome ores of North Carolina occur in granular olivine rocks (peridotites), which form numerous small isolated outcrops in a belt 5 to 25 miles wide throughout the mountainous western pait of the State, a distance of 200 miles. Most of the known deposits are in the middle part of this belt, extending from the mines at Webster, Jackson County, on the southwest, to the Ray mine, near Burnsville, Yancey County, on the northeast, a distance of about 75 miles. The prevailing rocks of the region are hornblendic and micaceous gneisses, but there are extensive areas of granite.

The olivine rocks form a part of the great Appalachian peridotite belt, which extends from Alabama to Newfoundland, a distance of more than 2,000 miles. Serpentine and soapstone, from the hydration of peridotites and closely related pyroxenites, are abundant in parts of the belt.

A notable variety of mining has been done in peridotite areas along this belt, which includes the great asbestos mines of Quebec and the smaller ones of North Carolina and Georgia ; the extensive soapstone quarries of Virginia ; the numerous corundum mines formerly worked in. North Carolina, Georgia, and Pennsylvania, some of which, in North Carolina, were recently revived; the serpentine quarries of Pennsylvania and Maryland; the iron mines of many years ago on Staten Island, N. Y.; and the nickel ores of North Carolina.

The first and for many years the only chrome ore mined in America was obtained from the serpentines of Maryland and Pennsylvania; later small quantities of ore were produced in North Carolina and still later in Quebec. Under the urgency of the recent war demand chrome ore wus produced at several places in Maryland, North Carolina, and Quebec.

This report describes the character of the rocks and their hydration and decomposition products, also the character and classification of the chrome ores and the nature of the gangue minerals.

Chromite, the essential ore mineral of all chrome ores, is a member of an isomorphous group which includes spinel, a compound of magnesia and alumina ; magnetite, a valuable iron ore ; franklinite, a prominent ore of zinc and manganese in New Jersey; and several other minerals of less economic importance. A characteristic property of these minerals is their capacity for the substitution of one chemical element for another during crystallization, thus giving rise to a wide range in composition. In chromite $\left(\mathrm{FeCr}_{2} \mathrm{O}_{4}\right)$, for example, part of the chromium may be replaced by aluminum and ferric oxide, and similarly magnesium may be substituted for a part of the ferrous oxide. The former process reduces the chromium content and therefore results in a mineral of less value, but the latter makes a desirable reduction in the percentage of iron. These variations may be represented in the formula thus: ( $\mathrm{Fe}, \mathrm{Mg}$ ) $(\mathrm{Cr}, \mathrm{Al}, \mathrm{Fe})_{2} \mathrm{O}_{4}$. 
In general the value of chrome ore depends primarily on its chromium content. For the chemical industry ores containing 50 per cent or more of chromic oxide $\left(\mathrm{Cr}_{2} \mathrm{O}_{8}\right)$ are generally sought. Lower-grade ores may be successfully smelted for the production of ferrochrome, but for this purpose a chromium-iron ratio of about 2 to 1 or higher is desired.

The total production of chrome ore in North Carolina to the end of 1918 is estimated at 392 tons, 116 tons of which still remains at the mines. Of this total 75 per cent is credited to the war years 1917 and 1918. Classified according to source, 11 per cent came from the washing of chromite-bearing soil, 33 per cent from disseminated ore in decomposed dunite, and 56 per cent from massive ore in lenses and pockets and from float ore, a few tons of which was obtained at some localities.

The ore mined at Webster came from pockets and lenses and from disseminated or "bird's-eye" ore in decomposed dunite. The disseminated ore furnished the chief supply in the recent operations. At Democrat chromite was recovered from residual soil by washing. At the Ray mine, near Burnsville, pockets of massive ore were worked. Prospecting was active in these and other parts of the region in 1917 and 1918, and some of this work produced several tons of ore, most of which was not shipped.

The chrome ores are believed to have been formed by the local concentration of suspended grains and crystals of chromite during the cooling of the molten peridotite magma after its intrusion into the gneisses. Convectional circulation was probably the chief agent in the process. The chance of large bodies of deeper-seated ore having been formed at the same time is thought to be very small.

A description of prospecting methods is appended for the benefit of those who are not familiar with the occurrence of chrome ore.

\section{INTRODUCTION.}

\section{IOCATION AND AREA.}

The chrome-ore deposits of North Carolina are restricted to a belt from 5 to 25 miles wide and 200 miles long, which extends across the mountainous west end of the State in a northeasterly direction, as shown in Plate VI. Mining of this ore has thus far been limited to a few scattered localities in a middle portion of this belt about 75 miles long, including Jackson County at the southwest and Yancey County at the northeast, although a small amount of prospecting has been done beyond these limits in both directions.

The field work on which this report is based was done in August and September, 1918, and consisted of brief visits to the chrome-ore mines and to many places where recent or earlier prospecting had been done. The work was undertaken as a part of the United States Geological Survey's investigation of supplies of ores and minerals essential to the prosecution of the war.

\section{ACKNOWLEDGMENTS.}

The examination of many widely scattered localities was greatly facilitated by the spirit of cooperation and assistance that was manifested by all who were in any way connected with the operations then 
in progress, and by owners, agents, prospectors, and others who had knowledge of either the recent or the earlier work in any part of the region. Special acknowledgments for valuable assistance are due to Mr. S. H. Hamilton, mining engineer, who was in charge of the Carolina Chrome Co.'s mines at Webster and Democrat; and to Mr. Fred H. Hemphill, who was manager of the Ray mine, near Burnsville, for the Southern Minerals Corporation.

\section{EARIIER INVESTIGATIONS.}

In the early seventies Rev. C. D. Smith, of Franklin, N. C., in his search for corundum throughout the western part of the State found and examined many of the peridotite areas with which the chrome ore is associated, and in a time of much controversy as to the origin of serpentine and peridotites he stoutly maintained their igneous character. After the publication of his papers in 1875 only occasional mineralogic notes and a few descriptions of isolated localities appeared in the literature until the writer began his investigation of these formations for the North Carolina Geological Survey, in the early nineties.

The problem of the nature and origin of the peridotites had then acquired economic importance from the active mining and prospecting for corundum. The study of these rocks and their associated minerals was continued intermittently by the writer in the midst of other duties for a decade, in the later years in collaboration on the mineralogic phase of the work with Joseph Hyde Pratt. The results were published in a bulletin and a series of papers in 1896, and finally in a joint monograph with Dr. Pratt in 1905. In the succeeding decade these rocks and minerals received little attention. The manufacture of artificial abrasives closed the corundum mines, and imported chromite supplied the domestic market for this ore. Then came the urgent demand and high prices of the World War period, which caused a renewal of operations in both chromite and corundum deposits, but for the former, at least, the stimulus produced only a temporary activity.

\section{IITERATURE.}

Smith, C. D., Corundum and its associated rocks: North Carolina Geol. Survey Rept., vol. 1, Appendix D, pp. 91-97, 1875. Describes the distribution and relations of the peridotites and the associated corundum. The rocks are regarded as igneous.

Șmith, C. D., Essay on the geology of western North Carolina: Idem, pp. 98120. Discusses the geology and ores of the crystalline rocks of the mountains.

Julien, A. A., The dunite beds of North Carolina: Boston Soc. Nat. Hist. Proc., vol. 22, pp. 141-149, 1882. Describes the gneissic dunites, giving the results of both field and microscopic examination, and concludes that they are probably stratified olivine sands. 
Wadsworth, M. E., Olivine rocks of North Carolina: Science, vol. 3, pp. 486487, 1884. A discussion of the preceding paper by Julien, arriving at the conclusion that the rocks are probably igneous.

Chatard, T. M., Corundum and emery: U. S. Geol. Survey Mineral Resources, 1883-84, pp. 714-720, 1885. Describes the peridotites at Corundum Hill, N. C., and the associated corundum.

Chatard, T. M., The gneiss-dunite contacts of Corundum Hill, N. C., in relation to the origin of corundum: U. S. Geol. Survey Bull. 42, pp. 45-63, 1888. Describes the rocks and their relations and gives many analyses of both rocks and minerals, including disseminated magnetic chromite. Analyses show the presence of chromium in nearly all materials.

Nitze, H. B. C., The chromic iron ores of the chrysolite rocks in Watauga, Mitchell, Yancey, Madison, Buncombe, and Jackson counties: North Carolina Geol. Survey Bull. 1, pp. 212-215, 1893. Gives analyses and describes the distribution of these ores and the attempts to mine them.

Glenn, William, Chrome in the southern Appalachian region: Am. Inst. Min. Eng. Trans., vol. 25, pp. $481-499,1896$. Describes the occurrence and mining of chrome ore in the serpentine of Maryland and Pennsylvania and compares the smaller bodies of less serpentinized rocks farther south.

Holmes, J. A., Corundum deposits of the southern Appalachian region: U. S. Geol. Survey Seventeenth Ann. Rept., pt. 3, pp. 935-943, 1896. Describes the distribution of the peridotites and the occurrence of corundum.

Lewis, J. V., Corundum and the basic magnesian rocks of western North Carolina: North Carolina Geol. Survey Bull. 11, 107 pp., 1896. Describes the character and distribution of the peridotites and associated rocks and the occurrence and distribution of corundum. Includes a bibliography and a geologic map of western North Carolina.

Lewis, J. V., Origin of the peridotites of western North Carolina: Elisha Mitchell Sci. Soc. Jour., vol. 12, pt. 2, pp. 24-39, 1896. Discusses the field and microscopic character of these rocks, and concludes that they are of intrusive igneous origin.

Lewis, J. V., Corundum of the Appalachian crystalline belt: Am. Inst. Min. Eng. Trans., vol. 25, pp. 852-906, 1896. Describes the peridotites, pyroxenites, etc., of the Appalachian region and northward to Newfoundland, together with the occurrence and distribution of corundum. Includes a bibliography and a map.

Pratt, J. H., The occurrence, origin, and chemical composition of chromite, with especial reference to the North Carolina deposits: Am. Inst. Min. Eng. Trans., vol. 29, pp. 17-39, 1900. Describes the occurrence and relations of the chrome ores and advances a theory of magmatic origin.

Pratt, J. H., and Lewis, J. V., Corundum and the peridotites of western North Carolina: North Carolina Geol. Survey, vol. 1, 464 pp., 1905. Full description and discussion of the geology, petrology, and mineralogy of the peridotites and the associated minerals, including economic consideration of corundum, chromite, asbestos, nickel ores, etc.

\section{GEOGRAPHY.}

The deposits of chromite, or chrome ore, described in this paper are situated in the mountainous section of western North Carolina (Pl. VI), in a belt of disconnected peridotite intrusives that lies almost wholly between the Blue Ridge on the east and the Great Smoky and Unaka mountains along the North Carolina-Tennessee 
boundary on the west. In contrast with the long parallel ridges of eastern Tennessee, this section of North Carolina, constituting a northeast-southwest belt 20 to 50 miles wide and approximately 200 miles long, is a plateau country lying mostly above an elevation of 2,500 feet and surmounted by numerous irregular mountain chains. Many of these ranges are only a score of miles or so in length, and some of them form branching and irregular groups.

This is the highest region of eastern North America. The average elevation is about 2,700 feet above sea level, but the crests of many ridges are over 5,000 feet, and a considerable number of peaks rise above 6,000 feet. The highest of these (Mount Mitchell, 6,711 feet) stands almost in the middle of the region. The mountains are steep and mostly forest covered, only the highest summits rising above timber line, and their slopes are trenched by deep, narrow ravines. The intervening uplands, which are extensively cleared and cultivated, have a rolling hilly surface, with broad, open valleys. Several of the larger rivers, however, have cut deep, narrow gorges with sides so steep and rugged as to constitute considerable obstacles to travel.

Almost the whole of this region is drained westward by Hiwassee, Tuckasegee, French Broad, Toe, and Watauga rivers, which pass through deep gaps in the intervening mountains and join Tennessee River in eastern Tennessee. At the north, however, the waters of New River contribute to the Kanawha, which flows northward across Virginia and West Virginia to the Ohio.

The central and southern parts of the region are traversed by lines of the Southern Railway system; the Carolina, Clinchfield \& Ohio Railroad crosses the north-central part; and the East Tennessee \& Western North Carolina Railroad enters the northern part of the belt from Johnson City, Tenn. There are also ten or twelve shorter lines in various parts of the region, most of which connect with these main lines.

\section{GEOLOGY.}

\section{APPALACHIAN CRYSTALIINE ROCKS.}

The prevailing rocks of this region are gneisses and crystalline schists of pre-Cambrian age, with many great bodies of intrusive granite, chiefly gneissoid, and numerous smaller masses of other igneous intrusives, most of which are also pre-Cambrian. Among these are numerous pegmatite dikes, which are mined at many places for mica, feldspar, and kaolin.

The foliation of the gneisses has a prevailing northeast strike, conforming to the general trend of the Appalachian ranges as a whole and parallel to the ridges and mountain folds of eastern Tennessee. The dip of the foliation is commonly at a steep angle toward 
the southeast, but in some places it is northwest, and the angle ranges from vertical to horizontal. Furthermore, the rocks in many parts of the region are crumpled and contorted in a complicated manner. Southeast of the mountains similar ancient crystalline rocks underlie the Piedmont Plateau, which here attains its maximum width of 140 miles. Overlying these rocks unconformably along the Tennessee border and in the southwestern counties of North Carolina are complexly folded, faulted, and metamorphosed Cambrian strata-sandstones, quartzites, slates, and schists.

In a belt 5 to 25 miles wide and 200 miles long through the central part of the North Carolina mountain region the gneisses are intersected by numerous small lenticular to rounded and tabular masses of peridotite and pyroxenite (Pl. VI). Few of these masses exceed a mile in length, although some are several miles long, and the width is generally about one-fourth to one-third as great as the length. Smaller masses grade down to diminutive outcrops only a few feet or even a few inches in diameter. These rocks occur most abundantly in the hornblendic Roan gneiss, but many are found also in the micaceous Carolina gneiss and schist, and others, possibly inclusions, are found in the Cranberry granite.

\section{APPALACHIAN PERIDOTITE BELT.}

\section{ChARACTER AND DISTRIBUTION OF THE PERIDOTITES.}

The peridotites and related rocks are parts of a great disconnected series extending from central Alabama to Newfoundland, a distance of more than 2,000 miles. In a short intervening area in New Jersey and two longer ones in Quebec later formations overlie the crystalline rocks into which the peridotites were intruded; but the striking uniformity in the character of the peridotites and their consistent alinement with the dominant structure of the older formations give abundant ground for regarding the whole series as a petrologic unit.

The degree of hydration of the rocks varies considerably in different parts of the belt. Serpentine abounds in Newfoundland and Quebec, although great masses of the original olivine rock still remain in Gaspe and the eastern townships. The peridotites of New York and New Jersey are completely serpentinized, as are many of those in Pennsylvania and Maryland, although in these States considerable bodies of talc have also been formed. Across Virginia the chief representatives of the series in many localities have become soapstone, with smaller bodies of serpentine and still less unaltered peridotite. In North Carolina, Georgia, and Alabama, although some masses have been changed entirely to ser- 


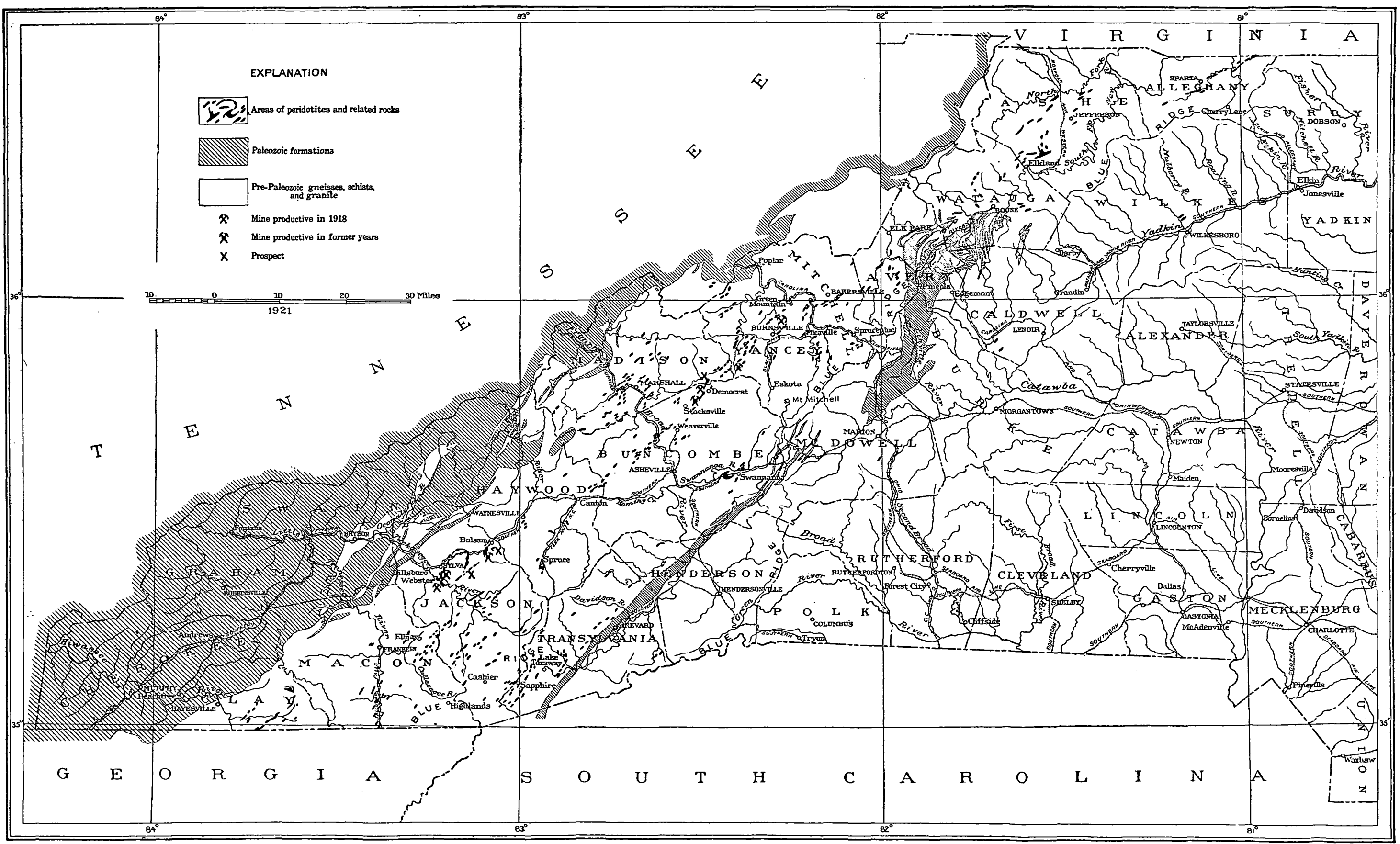


pentine and others are now largely talc, the great majority are either fresh peridotite and pyroxenite or only partly altered.

In different parts of the belt there is also great variation in the extent of the peridotite and serpentine areas. In contrast with the numerous small bodies of these rocks that characterize most of the Appalachian region, some of the serpentine areas of Maryland and Pennsylvania are more than 25 miles long, and the greatest area in the eastern townships of Quebec exceeds 35 miles in length.

MINING IN THE PERIDOTITES.

The Appalachian peridotite belt is the basis of a mining industry, past and present, which is notable for its great variety. The world's chief supply of asbestos is furnished by the partly serpentinized dunites of Quebec. The anthophyllite variety of asbestos has also been produced in considerable amounts from the peridotites of North Carolina and Georgia, and large quantities of such material are available. For many years corundum was actively mined from these rocks at numerous places in North Carolina, Georgia, and Pennsylvania. A soapstone industry that has rapidly taken first rank in the world's markets is established along this belt in the Piedmont counties of Virginia. Buildings in Philadelphia, Baltimore, Washington, and other cities have been constructed of serpentine from the quarries of Pennsylvania and Maryland. Genthite, the bright-green nickel silicate, has attracted the attention of prospectors at many places, and a few years ago an ambitious attempt was made in North Carolina to mine and smelt this ore. Iron ore was produced many years ago from the residual soil (laterite) of the serpentine area of Staten Island, $\mathrm{N}$. Y., as ore of similar character is mined to-day in northeastern Cuba. The first and for many years the only chrome ores produced in America came from the serpentines of Maryland and the southern border of Pennsylvania. Chrome ore is also mined at many places in the eastern townships of Quebec. For 40 years the pockets and irregular masses of chromite in the North Carolina peridotites have been the object of prospecting and occasional shallow-pit mining, and from time to time a few tons of surface lumps have also been gathered and shipped.

\section{PERIDOTITES IN NORTH CAROLINA.}

CHARACTER AND OCCURRENCE.

The 200-mile belt of gneisses and schists that extends through the mountainous section of western North Carolina contains numerous small intrusive bodies of peridotite and pyroxenite, as previously described. (See P.I. VI.) These appear chiefly in oval and lenticular outcrops a few score feet to a mile or more in length and generally 
about one-fourth to one-third as much in width. In a few exceptional areas the deposits are elongated to several miles, and some diminutive outcrops about Democrat range from less than a foot to 5 or 6 feet in diameter.

These peridotites and pyroxenites cut across the foliation of the gneisses in some localities and show branching or otherwise irregular forms, in keeping with their intrusive igneous character. In general, however, the outcrops are elongated in the direction of the gneissic structure, and many of them wedge out into thin talcose extensions that follow the foliation planes for hundreds of feet from the main body of the rock. Many of these masses are themselves strongly foliated; but there is great variation, even in neighboring outcrops, some of them, possibly later intrusions, retaining a perfectly massive structure.

A sheath of acicular anthophyllite commonly surrounds the peridotite or pyroxenite and separates it from the inclosing gneiss. The slender crystals and fibers range from an inch or so to more than a foot in length and are set at right angles to the bounding surface, forming a sort of "reaction rim" on a grand scale. Similar crystals occur along fissures and some of the master joints within the magnesian rocks. Outside of the anthophyllite sheath and next to the inclosing gneiss a layer of coarsely scaly to micaceous chlorite, from a few inches to several feet thick, is almost universal. In some localities talc accompanies or replaces the chlorite.

The pegmatite intrusions of this region are, in part at least, later than the peridotites, for they intersect the peridotites at some localities and are commonly found along the contacts. Rarely fine-grained aplite dikes are also found in the peridotites.

Pyroxenites are much less abundant than peridotites in this region, although considerable masses are known, and in some localities rocks of the two types are associated as parts of the same outcrop. Dunite, essentially the pure olivine rock, with scattered grains of accessory chromite, is the most common variety of peridotite. Some of the rock also contains enstatite, and where this mineral is abundant it forms with olivine the variety of peridotite known as harzburgite or saxonite.

An abundance of accessory chromite in parts of these rocks constitutes the disseminated chrome ore, which requires concentration. The segregation of this mineral into bodies of pure or nearly pure chromite within the rock produces the massive ore, which is commonly mined and shipped without other concentration than hand cobbing. Decay of the inclosing rock liberates the disseminated grains of chromite, which occur in the residual soil and in the sands of the streams and may accumulate in sufficient quantity and richness to be mined as chrome ore, to be further concentrated by washing. 
Large masses similarly released constitute the float ore, which has been collected and shipped from several localities.

The most abundant pyroxenite is the variety that consists almost entirely of enstatite. This rock has been called enstatite rock or enstatolite. It is somewhat common throughout the region and forms many masses of considerable extent. Websterite, which forms extensive outcrops at Webster, the type locality (fig. 25), and smaller masses in the vicinity, contains both orthorhombic and monoclinic pyroxenes-bronzite and diopside-in abundance. It forms a great intrusive mass in the midst of the foliated dunite at Webster and doubtless represents a differentiation product of the same magma.

Amphibole peridotite, troctolite (an olivine-anorthite rock), olivine gabbro, gabbro, amphibolite, and anorthosite are minor facies of the peridotites whose outcrops generally cover not more than a few square yards but locally have an extent of several acres. Bronzitite and hypersthenite, composed essentially of the more ferriferous varieties of the orthorhombic pyroxene, are rare.

\section{STRUCTURE OF THE PERIDOTITES.}

Many of the peridotites, including some of the largest masses, have a pronounced foliation, like that of the inclosing gneisses. The barren outcrop of dunite by the river at Webster is a good example. The websterite in the midst of this outcrop is less foliated, but the microscope shows that the structure in both is due, at least in part, to granulation by shearing along numerous closely set parallel planes. On the other hand, the foliation or banding in some peridotites, especially in much of the disseminated or partly segregated chromite, is undoubtedly original and due to rhythmic variations in the mineral constituents. In contrast with these gneissic types many outcrops are entirely massive and others are but slightly foliated or show foliation only locally, as about the contacts, in the thin extremities, or in the smaller offshoots from the main mass. Interlamination has been observed in several places, thin sheets of gneiss and peridotite alternating along the contacts. As previously noted, there is very generally a sheath of secondary minerals separating the basic magnesian rock from the inclosing silicic gneisses. Evidence of widespread later movement is found in the fact that everywhere at least a part of this sheath is schistose, even where the peridotite is entirely massive.

\section{HYDRATION PRONUCTS OF THE PERIDOTITES.}

Most of the peridotite outcrops in North Carolina are fresh-looking olivine rocks, except for the yellowish and brownish discoloration at the surface, due to weathering and incipient decomposition. The 
microscope shows, however, that in nearly all the outcrops some hydration has taken place along the cracks of the olivine grains throughout the mass of the rock; and in different localities all gradations can be found to complete alteration into yellowish-green or grayish-green or dark-green serpentine. Some serpentine contains scales of talc or chlorite in considerable amount, besides the accessory chromite of the original rock. Soapstone, a massive talc rock with disseminated chlorite and a hydration product of both peridotites and pyroxenites, is widely distributed in small amounts and is abundant in some localities. Much of it, however, has been foliated into talc schist. Chloritite, or massive chlorite rock, with some talc and chromite, derived by hydration from both peridotites and amphibolites, has also been extensively transformed into chlorite schist, which occurs abundantly in many parts of the region.

Contact sheaths and irregular veins of enstatite, anthophyllite (asbestiform in places), talc, chlorite, and vermiculite, separately or in various mixtures and banded arrangements, are almost universally found about both peridotites and pyroxenites. About the borders of many areas and extending some feet or scores of feet into the body of the rock, corundum occurs in rough barrel-shaped crystals or irregular grains, in confused mixture with chlorite and vermiculite and in some places with abundant biotite. On the other hand, both the corundum and the matrix minerals in some of these "veins" show a marked parallelism and orderliness of arrangement, and this may be the normal structure; if so, the prevailing confusion of such veinlike aggregates in this region is due to the compression and movement to which the inclosing rocks have been subjected since the peridotite intrusion. In a few localities corundum-bearing pegmatites occupy the central position in such chlorite veins.

\section{WEATHERING OF THE PERIDOTITES.}

Weathering produces a brownish discoloration of peridotites, pyroxenites, and serpentine and causes the rocks to crumble. Eventually they are converted into an ocherous mass with veinlets and nodules of chalcedony and commonly some drusy quartz. The magnesia of the original rock is removed in solution, and in places part of it is found in the veins below in the form of massive white or pink cleavable magnesite. Slabs, nodules, and honeycombed masses of chalcedony commonly occur with lumps of chromite on the surface and in the soil. Talc veins, on account of their greater resistance to weathering, stand out prominently on the outcropping ledges.

The proportion of soil-forming residue from the decomposition of these rocks is so small that many bare ledges are exposed in all the larger areas. Furthermore, this scant soil, besides offering insufficient water storage, is exceedingly infertile and hence supports only 
a meager growth of stunted vegetation. Thus arise the characteristic "barrens," except where the peridotites are so situated that soil from higher ground can supply their deficiency.

A small amount of nickel is a characteristic constituent of the peridotites. It is associated with magnesium and iron as a minor component of the mineral olivine. Green hydrous nickel silicates (genthite and perhaps garnierite) have been formed in numerous places by the weathering of the rocks, and the accumulation of these substances in the cracks of the rocks produces the bright-green coloration so often observed on breaking specimens from the outcrops and in the shallow prospecting pits and cuts.

\section{AGE OF THE PERIDOTItes.}

South of New Jersey the peridotites of the Appalachian belt are intrusive in granitic gneisses and crystalline schists, all of which seem to be certainly of pre-Cambrian age. In the New England States and Quebec, however, they penetrate strata which are considered although not proved to be Cambrian. At Hoboken, N. J., and on Staten and Manhattan islands, N. Y., their equivalent serpentines are found in the Manhattan schist, now generally believed to be of pre-Cambrian age but formerly called the Hudson schist, of Ordovician age. It may therefore be necessary to conclude either (1) that the Appalachian peridotites were intruded in Ordovician or post-Ordovician time or (2) that they are the products of two or more periods of igneous activity. Both the structural relations of the rocks and their petrology favor the latter hypothesis.

In several parts of the belt south of New Jersey the relations of these rocks to neighboring Cambrian strata afford strong presumptive evidence of their pre-Cambrian age. In Pennsylvania, Maryland, and Virginia the peridotites are represented chiefly by their hydration equivalents, serpentine and soapstone. Both of these rocks also occur in North Carolina, but most of the outcrops are still chiefly olivine rocks. Among these, however, some striking contrasts are found-in some areas typical fresh olivine rocks; in others rocks that are completely serpentinized; rocks of massive granular texture and others foliated into peridotite gneiss. Such contrasting types are separated in some localities by only a few rods of intervening gneiss. Manifestly the processes that affected the one rock in such places have not acted upon the other, and this seems to point to the intrusion of the unmodified rock at a later time. A dunite dike intersecting fresh harzburgite near Balsam, Jackson County, N. C. ${ }^{24}$ is obviously later, although there is no evidence as to the length of time that intervened between the solidi-

24 Pratt, J, H., and Lewis, J. V., Corundum and the peridotites of western North Carolina: North Carolina Geol. Survey, vol. 1, p. 46, pl. 10, A, p. 56, 1905. 
fication of the harzburgite and the intrusion of the dunite. Owing to a creep or slip of soil this dike was concealed from view in August, 1918.

Thus peridotite intrusions probably occurred during more than one period in North Carolina, even though all the peridotites may be preCambrian. Although direct evidence is lacking, the tentative hypothesis may be ventured that some of these intrusions were connected with the orogenic movements at the end of Ordovician time, and that others, including possibly those that formed some of the fresher massive peridotites of North Carolina, may have accompanied the greater Appalachian disturbance at the end of the Paleozoic era. Peridotite dikes that cut Ordovician, Silurian, and Devonian strata at several places in central New York and similar dikes in the Pennsylvanian, or "Coal Measures," of southwestern Pennsylvania and both eastern and western Kentucky are strongly suggestive of such relations.

\section{THE CHROME ORES.}

\section{HISTORY OF MINING.}

Many localities in western North Carolina have been prospected in a small way by pits and trenches, and several have yielded a few tons of chrome ore from pockets that appeared in the outcrops. Most of this work has been done in that part of the belt extending from Jackson County on the southwest to Watauga County on the northeast, a distance of about 100 miles. Prior to the recent war activity most of it was done 30 to 40 years ago, although a spasmodic interest in these deposits has appeared at intervals since. All work of the nature of mining in the past was confined to the natural segregations of massive chromite in the form of lenses, pockets, tabular masses, and irregular bodies.

Interest in the occurrence of chrome ore in North Carolina was aroused very early in the active search for corundum, which began in 1870. Prospectors soon observed that both minerals were associated with the peculiar peridotites along a northeasterly belt through the mountains. It was also early noted that the two were seldom, if ever, found in appreciable quantity in the same locality, the appearance of either in abundance indicating the scarcity or entire absence of the other.

No actual work in prospecting for chrome ore is known to have been done until the late seventies or early eighties. Then for 20 years there was occasional prospecting, accompanied from time to time by small mining operations, commonly limited to the blasting out of a pocket or two of ore that had been found in the outcrop. 
In some localities a few tons of float ore was also collected and shipped. Except in the vicinity of Webster and at Mine Hill, north of Burnsville, there was little attempt at thorough or systematic prospecting. Work was spasmodic in both mining and prospecting, the most promising localities were far from the railroads, the mountain roads were rough and steep, and hence no regular mining was ever established. When a mass of ore was found the usual procedure was to blast it out and abandon the workings, or at most to sink another shallow pit or two in the neighboring ground, in the hope of finding other pockets.

The demand for chromite during the war period led to more general prospecting in this region than ever before, but mining was restricted to three localities-Webster, Jackson County; Democrat; Buncombe County; and Mine Hill (the Ray mine), near Burnsville, Yancey County.

At Webster mining was begun for the Carolina Chrome Co. by S. H. Hamilton about October 1, 1917, and for three months in the following winter was continued until the demand ceased with the end of hostilities. Mr. Hamilton began operations at Democrat for the same company about May 1, 1918, and these were also continued until the end of the war. Fred H. Hemphill began getting out ore at the Ray mine for the Southern Minerals Corporation June 15, 1918, and stopped work with the end of the war.

\section{PRODUCTION.}

The total production of chrome ore in western North Carolina to the end of 1918 is estimated at 392 tons, 276 tons of which has been marketed. No complete statistics of early production are available, but from partial reports, supplemented by inquiry among people who were personally familiar with the operations in the different regions, it is estimated that 97 tons was produced before the revival of activity due to the recent war, and of this 72 tons was shipped. Most of this early production dates back to the eighties, and nothing definite is known as to the grade of the ore that was shipped.

In 1917 and 1918, under the stimulus of war prices, 204 tons was reported to have been shipped, including 25 tons from old ore piles; and, owing to shortage of cars, ore estimated at 116 tons was still at the mines when the demand ceased on the signing of the armistice. Of the ore shipped 130 tons was reported to have contained over 50 per cent of chromic oxide. 


\section{CHARACTER OF THE ORES.}

\section{CLASSIFICATION.}

The deposits of chromite, the only chrome-ore mineral, may be classified as primary and secondary, and these in turn may be subdivided as follows:

Primary ores:

Segregated lenses and pockets; massive ores.

Disseminated or partly segregated ore.

Secondary ores:

Float, or surface blocks of ore.

Residual ore, in the soil.

Alluvial or placer deposits, in stream sands.

PRIMARY ORES.

Massive ores.-None of the primary ore occurs in forms that may properly be called true veins. Chromite in small scattered black grains and crystals is one of the most constant and characteristic constituents of the peridotites everywhere. In some places this mineral is found in granular aggregates, more or less mingled with rock, or in more solid masses of nearly pure chromite ranging from less than an inch to several feet in thickness. These constitute the segregated type of primary ore, which has always furnished the great bulk of chrome ore on the market.

Many of the ore masses are lens-shaped isolated pockets in the rock. Here and there, however, two or more such bodies are connected by thin stringers of ore. Spheroidal and ellipsoidal shapes are also found, and some that are flat and tabular, besides intermediate forms and irregular, shapeless masses. Tabular masses of some continuity simulate the appearance of true veins and are often so called by the miners. In North Carolina the ore pockets are small, the great majority containing from a few hundred pounds to a few tons each and only exceptional pockets yielding as much as 15 or 20 tons.

Disseminated ore.--Those parts of the rock that contain a great abundance of accessory chromite grains, although mixed with a large amount of olivine, are sufficiently abundant and rich in some localities to constitute a workable ore of the disseminated or partly segregated type, sometimes called "spotted" or "bird's-eye" ore. Such bodies are found about some of the pockets or masses, and gradations between the two types occur at many places. Most commonly the disseminated ores are foliated or have a banded structure, owing to the alternation of richer and poorer layers. An extreme variation of this type, not uncommonly seen, consists of thin sheets of chromite alternating with layers of barren dunite and in places 
a system of irregular stringers, branching and anastomosing through the rock.

Some of this spotted, banded, and streaked ore is associated with many of the massive lenses and pockets, but it has generally been disregarded. The larger and richer bodies of such material, however, especially where it has to be mined and hoisted in connection with the accompanying pockets, can probably be made to supplement the production without disproportionate cost.

Both the massive and the disseminated primary chrome ores, through increasing admixture of rock material, show at many places gradual transitions to normal peridotite. On the other hand, welldefined walls are not uncommon, and some of these show striations and slickensiding, due to movement after the segregation of the ore.

The lenses, pockets, and disseminated ores occur in the peridotites, and almost without exception they are found near the contacts with the inclosing gneiss, and their broader dimensions are parallel to the contact plane. The interlamination of chromite and peridotite seen in so much of the disseminated ore takes the same direction. Exceptions to this mode of occurrence are few and small, and none that gives promise of importance has been found in this region. All known chrome ores in the southern Appalachian region also occur either in peridotite or in serpentine resulting from the hydration of peridotite. No notable amounts of ore have been found in pyroxenite or in any of the minor accompanying bodies of gabbroic and dioritic rocks.

\section{SECONDARY ORES.}

Float or surface ore.-Surface blocks of ore result from the release of massive lumps of chromite by the disintegration and decay of the inclosing rock through surface weathering. Chromite is very resistant to such processes, and hence with the crumbling away of the parent rock and the removal of much of the fine residual soil by erosion the masses of ore tend to accumulate on the surface. It follows that an abundance of float does not necessarily indicate the occurrence of correspondingly large bodies or numerous pockets of workable ore in the underlying rock.

Float ore has been a minor source of chromite where boulders were gathered up and shipped with massive ore from the mines. Except possibly in some of the more remote districts, little further production is to be expected from this source.

Residual ore.-The concentration of chromite in the residual soil, like the formation of the float ore just described, is also a result of weathering. With the crumbling of disseminated ore the heavy refractory grains of chromite are liberated, and they may be recovered from the residual products of decay by washing away the lighter 
and more pulverulent products. Generally this process of concentration has already taken place to a certain extent in the erosion of the surface soil by rain wash during the slow process of decomposition. A word of caution is therefore appropriate here also-a high percentage of chromite in residual soil does not point to a corresponding richness in the rock beneath.

Residual chromite-bearing soil has been the basis of mining at Democrat, Buncombe County, where 30 to 40 tons of high-grade concentrate was awaiting shipment when the work was stopped at the cessation of hostilities. A considerable area of washable ground has been tested at this place, and larger areas here and in the vicinity seem worthy of investigation. Some of the ore produced at Webster also came from chromite-bearing residual soil.

Alluvial or placer deposits.-Alluvial or "sand" chrome-ore deposits originate from erosion of the surface by rain wash and the action of streams, the two processes cooperating in the transportation of the residual products of decay. The removal of the lighter and the more minutely divided materials and the consequent segregation of the larger and much heavier grains of chromite is performed far more effectively in flowing streams than by rain wash on the land. This statement does not apply, however, to those swift mountain torrents that are able to sweep away both the chromite and the lighter materials. Stream concentration under favorable conditions may give rise to accumulations of ore of sufficient extent and high enough quality to make recovery profitable. The further concentration of such ore after mining is an artificial continuation of the natural method that produced the deposits.

Stream sands have been mined in Maryland, and it is said that some of them have been reworked profitably at intervals of about 15 years. Similar sands have been tested at a few places in North Carolina, but the chromite content proved to be too low for mining. Most of the mountain streams are so swift at flood time that both ore and rock particles are swept away together, and there seems little likelihood that any of them will furnish minable deposits.

\section{MINERALOGY OF THE ORES.}

Chromite.-Chromite is the only mineral of importance as an ore of chromium. Its habit in the North Carolina peridotite ranges from irregular and rounded grains to perfectly formed octahedral crystals. In certain localities, as about Democrat, in Buncombe and Madison counties, perfect crystals are strikingly abundant. They are the chief constituent of the concentrate at the Carolina Chrome Co.'s mine at Democrat, making it a remarkably brilliant and attractivelooking product. Most of the grains and crystals in both the normal 
rock and the disseminated ores are less than one-twelfth of an inch (2 millimeters) in diameter, although a few measure about a quarter of an inch (6 or 7 millimeters). In the massive ores a granular habit, without crystals, is very common; also the purer masses at some localities break with a conchoidal fracture and a glossy black pitchy surface in which there is no suggestion of granularity. Olivine grains in such ore have the appearance of inclusions in a continuous solid mass. Some chromite is attracted by the magnet like magnetite, although commonly less strongly, and such ore is likely to be mistaken in the field for the iron ore.

In thin section under the microscope the accessory grains of chromite in the peridotites very commonly show some translucence, especially on the thinnest edges. The color by transmitted light varies from pale yellowish brown (in the picotite, or magnesian variety) to dark reddish brown and brownish black. The luster by reflected light varies in a similar manner, the dullest appearance accompanying the brown color and the blackish opaque grains showing a submetallic luster.

Composition of chromite.-Variations in color, luster, and degree of translucence are comprehensible in view of the chemical character of chromite. Theoretically it is commonly represented by the formula $\mathrm{FeCr}_{2} \mathrm{O}_{4}$ (or $\mathrm{FeO} . \mathrm{Cr}_{2} \mathrm{O}_{3}$ ), and a specimen having this composition would contain 67.86 per cent of chromic oxide $\left(\mathrm{Cr}_{2} \mathrm{O}_{3}\right)$. Few specimens, however, even of the purest mineral and free from admixture of gangue, run above 60 per cent of $\mathrm{Cr}_{2} \mathrm{O}_{3}$, and analyses range from this content down to 35 per cent and lower. This diversity of composition is due to the chemical habits of the spinel group of minerals, which includes chromite, also magnetite, an important iron ore, and franklinite, an important ore of zinc and manganese in New Jersey. The group is named for the magnesian member, spinel $\left(\mathrm{MgAl}_{2} \mathrm{O}_{4}\right)$, and the composition of all the members is represented by formulas of the same type.

The spinel group is one of the best examples of isomorphous replacement, or substitution of one chemical element or group of elements for another. This characteristic assumes a practical importance on account of the close relation between the chemical composition of an ore and its commercial value. When chromite is crystallizing, for example, a part of the ferrous oxide may be replaced by . magnesium, which is an abundant constituent of the peridotites; and in a similar manner aluminum and ferric oxide, if present, may be substituted for a part of the chromium. The latter process reduces the chromium content and therefore results in a mineral of less value; the former makes a desirable reduction in the percentage of iron. Such replacements of chemical constituents are equivalent to mixing together molecules of chromite $\left(\mathrm{FeCr}_{2} \mathrm{O}_{4}\right)$ with spinel $\left(\mathrm{MgAl}_{2} \mathrm{O}_{4}\right)$, 
hercynite, or iron spinel $\left(\mathrm{FeAl}_{2} \mathrm{O}_{4}\right)$, and magnetite $\left(\mathrm{FeFe}_{2} \mathrm{O}_{4}\right)$, and may be represented in a single formula thus: $(\mathrm{Fe}, \mathrm{Mg})(\mathrm{Cr}, \mathrm{Al}, \mathrm{Fe})_{2} \mathrm{O}_{4}$.

Specimens of Maryland sand chrome ore that were separated into magnetic and nonmagnetic portions and analyzed by Joseph $\mathrm{T}$. Singewald, jr., ${ }^{25}$ yielded the following interesting results when calculated into the molecular percentages of the above-named minerals:

Molecular constitution of Maryland sand chrome ore.

\begin{tabular}{|c|c|c|c|c|c|}
\hline & \multirow{2}{*}{$\begin{array}{c}\text { Per cent of } \\
\text { total. }\end{array}$} & \multicolumn{4}{|c|}{ Molecular percentages. } \\
\hline & & $\mathrm{MgAl}_{2} \mathrm{O}_{4}$ & $\mathrm{FeAl}_{2} \mathrm{O}_{4}$ & $\mathrm{FeCr}_{2} \mathrm{O}_{4}$ & $\mathrm{FeFe}_{2} \mathrm{O}_{4}$ \\
\hline 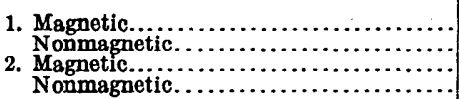 & $\begin{array}{r}56.5 \\
43.5 \\
5.9 \\
94.1\end{array}$ & $\begin{array}{r}16 \\
19 \\
0 \\
19\end{array}$ & $\begin{array}{r}4 \\
20 \\
8 \\
45\end{array}$ & $\begin{array}{r}31 \\
52 \\
3 \\
10\end{array}$ & $\begin{array}{r}49 \\
9 \\
89 \\
26\end{array}$ \\
\hline
\end{tabular}

Thus in the two magnetic portions 49 and 89 per cent of the molecules, respectively, were found to consist of magnetite; and 84 and 100 per cent, respectively, contain iron. In the nonmagnetic portions the figures show 9 and 26 per cent of magnetite, and the total of the iron-bearing molecules was found to be 81 per cent in each sample.

The following analyses of chromite, some of which was not entirely free from gangue minerals, will illustrate the great range in composition to which these ores are subject.

Analyses of chromite.

\begin{tabular}{|c|c|c|c|c|c|c|}
\hline & 1 & 2 & 3 & 4 & 5 & 6 \\
\hline \multirow[t]{2}{*}{ 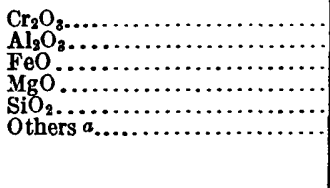 } & 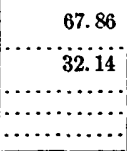 & $\begin{array}{r}63.37 \\
1.95 \\
30.04 \\
2.21 \\
2.02\end{array}$ & $\begin{array}{r}60.04 \\
11.85 \\
20.13 \\
7.45 \\
\cdots \cdots+\cdots \\
\end{array}$ & $\begin{array}{r}59.20 \\
7.15 \\
25.02 \\
4.42 \\
3.20 \\
.92\end{array}$ & $\begin{array}{r}58.00 \\
15.52 \\
14.45 \\
8.26 \\
3.20 \\
.70\end{array}$ & $\begin{array}{r}57.20 \\
7.82 \\
25.68 \\
5.22 \\
2.80 \\
.69\end{array}$ \\
\hline & 100.00 & 99.59 & 99.47 & 99.91 & 100.13 & 99.41 \\
\hline \multirow[t]{2}{*}{ Atomic ratios, $\mathrm{Cr}: \mathrm{Fe} . \ldots \ldots \ldots$} & $2.00: 1$ & $2.00: 1$ & $2.83: 1$ & $2.24: 1$ & $3.80: 1$ & 2. $13: 1$ \\
\hline & 7 & 8 & 9 & 10 & $11^{\prime}$ & 12 \\
\hline \multirow[t]{2}{*}{ 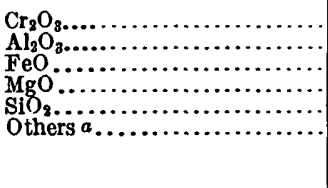 } & $\begin{array}{r}51.60 \\
14.62 \\
18.09 \\
13.06 \\
1.40 \\
1.14\end{array}$ & $\begin{array}{l}49.75 \\
11.30 \\
21.28 \\
18.13 \\
\cdots \cdots \cdots \\
\cdots \cdots\end{array}$ & $\begin{array}{r}45.94 \\
2.51 \\
42.90 \\
3.91 \\
3.20 \\
1.32\end{array}$ & $\begin{array}{r}42.20 \\
13.60 \\
23.84 \\
14.88 \\
\quad 5.48 \\
\quad 5\end{array}$ & $\begin{array}{l}39.95 \\
29.28 \\
13.90 \\
17.31 \\
\cdots\end{array}$ & $\begin{array}{r}34.25 \\
25.36 \\
17.07 \\
19.07 \\
2.10 \\
2.11\end{array}$ \\
\hline & 99.92 & 100.46 & 99.78 & 100.00 & 100.44 & 99.96 \\
\hline Atomic ratios, $\mathrm{Cr}: \mathrm{Fe} \ldots \ldots \ldots$ & $2.64: 1$ & $2.22: 1$ & $1.01: 1$ & $1.68: 1$ & $2.72: 1$ & $1.74: 1$ \\
\hline
\end{tabular}

a Minor constituents, as follows: (2) $\mathrm{CaO} 2.02$; (4) $\mathrm{MnO} 0.92$; (5) $\mathrm{CaO} 0.70$; (6) $\mathrm{MnO} 0.69$; (7) $\mathrm{Fe}_{2} \mathrm{O}_{3} 0.50$, $\mathrm{CaO} 0.24$, Ign. 0.40; (9) $\mathrm{MnO} 0.84, \mathrm{TiO}_{2}$ 0.36, $\mathrm{P}_{2} \mathrm{O}_{6} 0.12$; (12) $\mathrm{Fe}_{2} \mathrm{O}_{2}$ 1.77, Ign. 0.34 .

25 Econ. Geology, vol. 14, pp. 189-197, 1919. 
1. Composition of the simple chromite molecule, $\mathrm{FeCr}_{2} \mathrm{O}_{4}$.

2. Baltimore. Dana's Mineralogy, 5 th ed., p. 153 ; A. Rivot, analyst.

3. Baltimore. Idem; Abich, analyst.

4. Price Creek, Yancey County, N. C. North Carolina Geol. Survey, 'vol. 1, p. 373 ; Charles Baskerville, analyst.

5. Mine Hill, Yancey County, N. C. Idem, p. 382 ; Charles Baskerville, analyst.

6. Corundum Hill, Macon County, N. C. Idem, p. 373 ; Charles Baskerville, analyst.

7. Glenn County, Calif. U. S. Geol. Survey Mineral Resources, 1914, p. 8; Mutual Chemical Co. of America, analyst.

8. Lake Memphremagog, Quebec. Dana's Mineralogy, 5th ed., p. 153; T. Sterry Hunt. analyst.

9. Corundum Hill, Macon County, N. C. U. S, Geol. Survey Bull. 42, p. 52; 'T. M. Chatard, analyst.

10. California. Ries, H., Economic geology, 4th ed., p. 790.

11. Webster, Jackson County, N. C. North Carolina. Geol. Survey, vol. 1, p. 373 ; H. W. Foote, analyst.

12. Sonoma County, Calif. U. S. Geol. Survey Mineral Resources, 1914, p. 11 ; Mutual Chemical Co. of America, analyst.

Some of these analyses were made from selected specimens, and hence they do not represent the average quality of ore to be found in the localities from which they were taken. No. 11, for example, comes from a district that has recently furnished several carloads of good ore, some of which contained more than 50 per cent of $\mathrm{Cr}_{2} \mathrm{O}_{3}$. On the other hand, it is obvious from the analyses that from ores which have an average composition like that of Nos. 10, 11, and 12 it will be impossible to produce a high-grade concentrate by any process of beneficiation. Thus a definite limit to the percentage of chromic oxide that an ore or concentrate may contain is set by the chemical composition of its contained chromite, the essential ore mineral.

Relation of composition to use and value.-The commercial value of chrome ore depends in general on its content of chromic oxide. For use in the chemical industry ores containing at least 50 per cent of $\mathrm{Cr}_{2} \mathrm{O}_{3}$ are generally sought. Lower-grade ores may be smelted successfully for the production of ferrochrome, but for this purpose a chromium-iron ratio of 2:1 or higher is desired. Experience has shown that it is difficult to produce ferrochrome with a high chromium content, say 65 to 70 per cent, from ores that contain a higher proportion of iron than that indicated by the ratio mentioned. ${ }^{26}$ Some of the analyses quoted in the accompanying table are notably below this standard, but a large number show a higher ratio of chromium to iron, owing to the partial substitution of magnesium for iron in the chromite molecule.

The heavy loss of chromium in the slag produced in the furnace by the gangue minerals emphasizes the importance of properly cleaning and concentrating the ore for metallurgic use.

There is also a market for the lower-grade ores as refractory materials, both for furnace lining, as crude lumps, and for manufacture into chrome brick.

${ }^{20}$ Keeney, R. M., The manufacture of ferroalloys in the electric furnace: Am. Inst. Min. Eng. Bull. 140, pp. 1321-1373, August, 1918. 
Primary gangue minerals.-The gangue minerals in chrome ores are the normal constituents of the rock or secondary products derived from their alteration. As the dominant types of rocks accompanying the ore deposits are dunite and similar olivine-rich peridotites, the most abundant gangue mineral is olivine, and in the disseminated or partly segregated and laminated ores this is generally the only one of importance. In harzburgite there is also some of the magnesian pyroxene, enstatite. At the Ray mine tremolite is notable in some of the workings, where it forms whitish to bright-green parallel and interlacing crystals, some of which are half an inch broad and several inches long.

Secondary gangue minerals.-Magnetite is an associate of chromite in some of the peridotites, but its presence as a primary constituent in massive chrome ore has not been demonstrated. In thin sections under the microscope its steel-gray color and strong metallic luster serve to distinguish it from the duller brown to black chromite. Most of it is concentrated in the thin films of serpentine that so commonly separate the olivine grains, and in such places it is obviously secondary. Much of it also differs from the associated chromite in being disseminated as fine dustlike particles and in not showing crystal forms.

From the chrome-ore concentrate from the mine at Democrat a weakly magnetized knife blade drew out particles that were readily soluble in dilute hydrochloric acid. The solution yielded a strong test for nickel, which seems to point to the derivation of the magnetite from decomposing olivine. Many small crystals of chromite were also withdrawn with the magnetite. Some of these had visible accretions of secondary magnetite adhering to them; others that seemed to be perfectly clean crystals, with bright, glistening faces, doubtless possess original magnetism due to a high iron content. Only clean, brilliant crystals and grains of chromite remained after treatment with acid, and some of these were still attracted by the magnet.

Other secondary minerals occur in considerable abundance, especially in the lenses and pockets of massive ore. The most common of these are talc and chlorite in minute scales intimately mingled with granular chromite. The two scaly minerals are associated in all proportions, but some ores are impregnated with either talc or chlorite alone. Not uncommonly kämmererite, the lavender-colored chrome-bearing chlorite, accompanies the common dull-green varieties, and in some deposits this mineral constitutes practically the whole volume of the gangue. Veins of kämmererite intersect the massive ores at some places, commonly ranging from paper-like films to bodies about a quarter of an inch thick. At the Webster mine of the Carolina Chrome Co. such veins 2 to 3 inches thick are abundant 
in some parts of the ore. Most of these veins are dense aggregates of extremely minute scales, but some have distinctly visible texture, and rarely scales as much as an inch or more across are found.

The many species and varieties of chlorite, in aggregates of large or small flakes and in bodies having parallel schistose structure, are subject to further hydration into a long series of green, brown, and golden-yellow micaceous and scaly vermiculites. All stages in the process of transformation are found. Biotite also undergoes a similar change.

Where peridotite has been changed into serpentine the serpentine takes the place of the original olivine rock as the matrix of the massive and disseminated ores. It is intersected in some places by small veins of chrysotile, the serpentine asbestos. Enstatite, where present in the original rock, has generally been hydrated, at least in part, to talc not only in the serpentines but also in many places where the olivine remains unchanged.

Genthite and perhaps garnierite or other light-green hydrous nickel silicates are common in small amounts in cracks in the rocks and ores at most of the peridotite localities. The formation of these silicates is dependent on the weathering of the nickel-bearing olivine; hence, they are not found far below the surface. A deep grassgreen mineral that forms films in the joints of massive chromite at some localities may possibly be uvarovite, the chrome garnet, although the presence of this mineral in the North Carolina region has not been definitely determined.

Magnesite, the magnesium carbonate, derived from the surface weathering and decomposition of the peridotite, is sometimes found in joint cracks or fissures with chrome ore. Veins of white and palepurplish magnesite, 3 inches thick, showing broad rhombohedral cleavage faces, were encountered in one of the shafts of the Carolina Chrome Co. at Webster.

Silica, also from decaying peridotite, is found in cracks and fissures in some places to a depth of 20 feet or more from the surface in the form of films, veins, and irregular masses of white and yellowish chalcedony, commonly with a little drusy quartz and a little opal in opaque white or transparent colorless botryoidal aggregates. At Webster white chalcedony replaces dunite in flat-lying layers several inches thick and approximately parallel to the surface. Where these layers cross the disseminated and banded ores the olivine is entirely replaced, but the chromite remains unaffected and retains its original distribution.

Corundum and its associates.-Corundum in grains, crystals, and massive aggregates accompanies many of the peridotite outcrops in western North Carolina, chiefly in the chlorite-vermiculite sheaths that nearly everywhere mark the contacts of the peridotite intrusions. 
Experience has shown, however, that corundum and chrome ore are not associated in considerable amounts, and prospectors recognize the fact that where one of these is plentiful there is likely to be little or none of the other, although chromite in scattered grains is everywhere an accessory constituent of the peridotite.

Where corundum occurs in any appreciable quantity it is associated with a remarkable abundance and variety of other minerals, including massive green spinel, albite, and other species of plagioclase feldspar, several varieties of amphibole and pyroxene, zoisite, black tourmaline, biotite, margarite, and apatite, besides a number of other species that occur only in small amounts or at few localities.

\section{ORE DEPOSITS.}

\section{OCCURRENCE.}

Chromite grains are scattered through the granular olivine rocks everywhere and occur also in serpentine and soapstone derived from these rocks. In some places this accessory constituent is so abundant as to attract attention as a possible ore, and rock of this character was crushed and the chromite concentrated in connection with mining in the more decomposed facies of dunite at Webster. In the fresh rock, however, neither the scattered lumps and stringers nor the disseminated grains have proved profitable as a basis of mining operations in North Carolina because of the high cost of mining, crushing, and concentrating.

Small masses of float chromite, from a few ounces to a few pounds in weight, are associated with peridotite outcrops in many parts of the Appalachian peridotite belt, and pockets of similar material are found in places in the outcrops and in prospecting pits and cuts.

No attempt is made here to describe all the localities where pockets and stringers of chrome ore have been found in North Carolina. Many of the pockets were so small or so scattered as to discourage prospecting; others, farther from the railroads or situated in the more rugged parts of the mountains, have attracted little attention. Some of the numerous places where float ore is found seem, for one reason or another, to have escaped the notice of the prospector altogether. Hence knowledge of the ore conditions in many of the peridotite areas is meager or wanting. The descriptions that follow, however, include all localities where mining or any considerable amount of prospecting has been done.

\section{DEPOSITS AT WEBSTER AND VICINITY.}

Geography.-Chromite pockets and bodies of disseminated ore have been found in the borders of the dunite outcrop at Webster, 
Jackson County, over an area extending a quarter of a mile north of the village and $1 \frac{1}{2}$ miles south and southeast (fig. 25). Most of the recent work has been done in the southern part of this area, south of Tuckasegee River, which here flows in a general westerly course less than half a mile south of Webster.

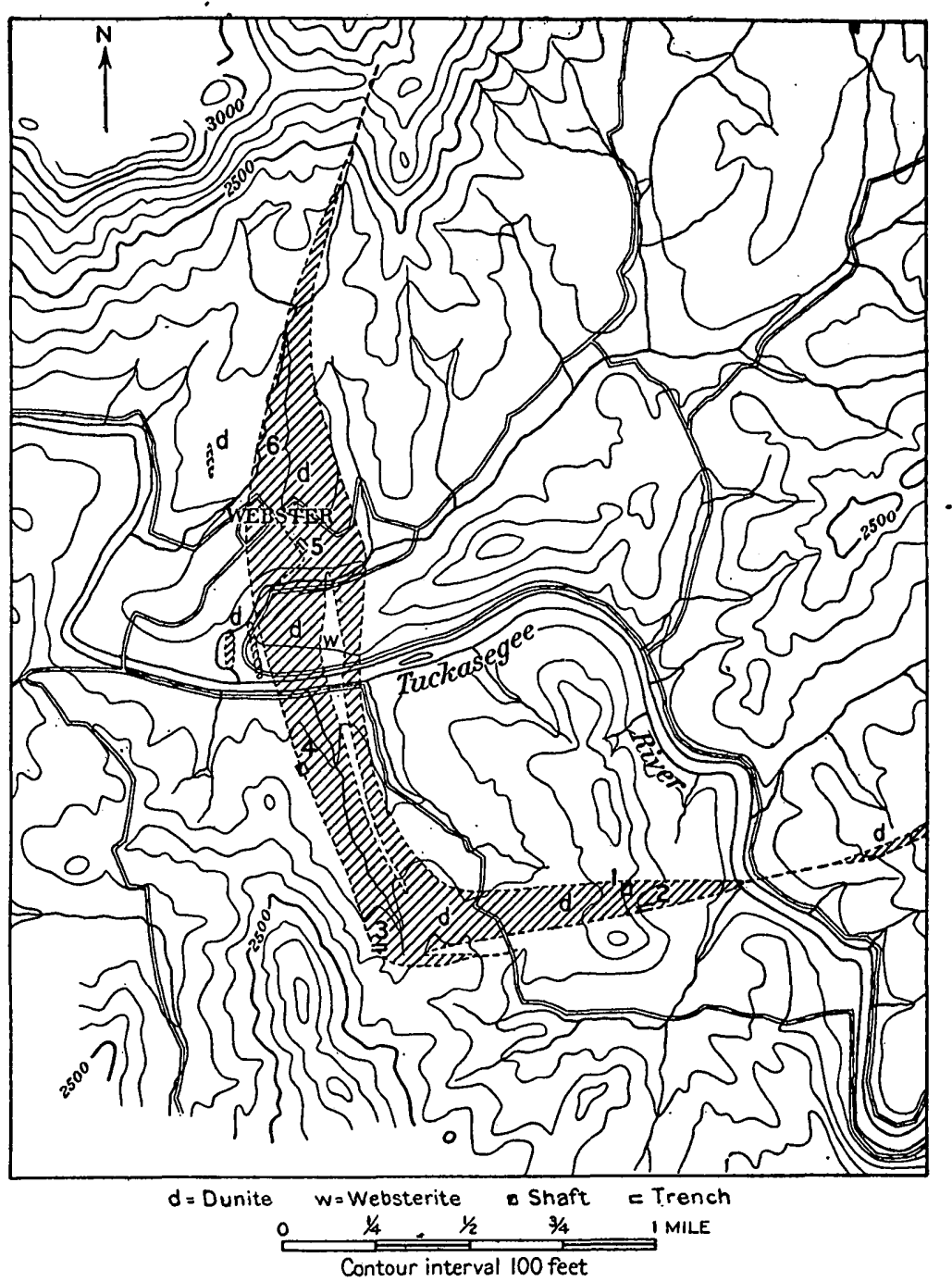

Frgure 25.-Map showing peridotite, pyroxenite, and chrome workings about Webster, N. C. Shading indicates areas underlain by dunite. Numbers refer to localities mentioned in the text.

The surface is hilly, with general slopes toward the river and a maximum relief within the ore-bearing area of 300 feet. Adjacent mountain groups on every side, however, rise 1,200 to 1,500 feet above the Tuckasegee Valley, and the neighboring ranges, of which these 
are the spurs and outlying foothills, rise more than 4,000 feet higher, to a maximum elevation of 6,399 feet above sea level at Water Rock Knob. Good dirt roads connect with Sylva, the county seat, and with Dillsboro-both on the Southern Railway, 3 miles distant. The slopes of all the mountains are covered with forests except the few peaks that rise above timber line, and Tuckasegee River provides an abundance of water and power for use in mining and milling. Much of the peridotite area is nearly barren of vegetation, but the broad strip of websterite in the midst of the dunite supports, in contrast, a fair forest growth.

Geology.-The Webster peridotite area is the largest in the State. The usual lenticular outline is masked by an abrupt turn in the outcrop south of the village, in conformity with the structure of the inclosing gneiss. Dunite, the principal rock, is almost everywhere strongly laminated parallel to the contacts, and the foliation, like that of the gneiss, dips steeply south and southwest. In the village and near the north bank of the river shallow cuts and roads formerly exposed cross sections that showed slabs of gneiss within the peridotite, or possibly local sheets of peridotite 10 to 12 feet thick parallel to the contact of the main intrusion and separated from it by only a few feet of gneiss. Larger separate bodies, doubtless connected in depth with the main mass, crop out near the river at distances of 100 and 400 feet from the western contact, as shown on the map (fig. 25). A thin extension also branches off into the gneiss at the south.

The maximum width of the Webster peridotite area is 1,600 feet. A little east of the middle is the large body of websterite, the type occurrence, which is 550 feet wide on the slope north of the river. This rock is distinctly less foliated than the dunite and is doubtless a later intrusion from the same magma. Its strict conformity to the lamination of the dunite shows that this structure was well developed before the websterite intrusion. The moderate foliation of the websterite, however, points to a recurrence or continuance of the dynamic disturbance. Another small body of websterite is found in dunite 3 miles east of Webster, on Cane Creek 1 mile above its mouth. These two are the only localities in the State where pyroxenite of this type has been found.

History.-Besides a little desultory mining a generation ago, when a few tons of chrome ore was taken now and then from shallow pits and open cuts, there was little attention given to the deposits in this region until the summer of 1917, when S. H. Hamilton prospected the district about Webster and northeastward toward Balsam for the Carolina Chrome Co. He began operations at the location of the present mine about October 1, 1917, by hand methods, hauling the residual ore down the hill half a mile westward to a washing box on a small branch. About $1 \frac{1}{2}$ carloads of concentrate was 
produced in this way. A table and jig were then set up and operated at the same place about January 1, 1918; but the work was soon stopped by legal complications, which were not cleared up till some time in March, and about the middle of that month the mill was started at its present location at the mine. All told, about 130 tons of concentrate was shipped before operations were discontinued December 1, 1918.

Occurrence of the ores.-Following the occurrence of float ore, prospectors have sunk shallow pits at many places at and near the contacts. Small scattered masses of chrome ore were found very generally immediately along the contacts, and several promising bodies of ore were encountered there and also within the dunite near the contacts. The cut at locality 3, figure 25, and the Carolina Chrome Co.'s mine at locality 1 also show considerable quantities of disseminated ore. All recent work has been confined to the border deposits.

An old pit recently reopened at locality 5 , in the middle of the dunite, shows only thin stringers of chromite, but the remnant of an old ore pile contains blocks of ore from larger bodies. Ore is said to have been shipped from this pit a generation ago. So far as known this is the only place where deposits have been sought in the midst of the dunite in this district. Many pits, cuts, and prospecting ditches have been opened in different parts of the area, both north and south of the river, in the search for nickel ore. Genthite, the green hydrous silicate of nickel, is unusually abundant in this locality, but attempts to exploit it as an ore have not been successful.

The following analysis of chrome ore from Webster probably represents the cut at locality 5 , which was one of the earliest workings in the district.

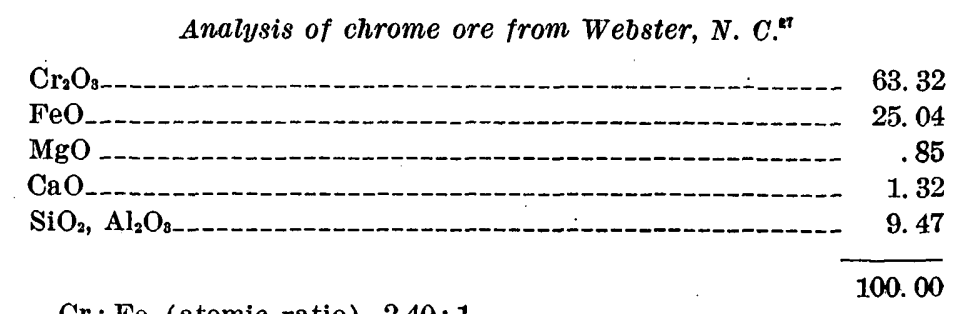

$\mathrm{Cr}: \mathrm{Fe}$ (atomic ratio), 2.40:1.

Carolina Chrome Co.'s mine.-Active mining was carried on in 1917 and 1918 by the Carolina Chrome Co. on the property of Ann Wilson, $1+$ miles southeast of Webster in a direct line, in a low gap on the crest of a north-south ridge about 250 feet above the level of the river. All workings are entirely within the dunite area near the north contact with the gneiss. The exact contact is concealed by soil cover and has not been prospected at this locality. Decomposed gneiss is recog-

27 Kerr, W. C., North Carolina Geol. Survey Ann. Rept., vol. 1, p. 293, 1875. 
nizable, however, in surface ditches within 40 feet of the mine workings.

The openings at the mine are on a nearly horizontal east-west line on a gentle south slope. The principal shaft ( $a$, fig. 26), 70 feet deep, headframe, and mill are at the east end. West of the shaft and connected with it is an open cut $(b), 20$ by 40 feet and 30 feet deep, with a drift extending 125 feet farther west from the bottom. Over this drift and separated from open cut $(b)$ by a space of 35 feet is another open cut $(c), 70$ feet long and 25 feet deep. At 50 feet west of this cut is a prospecting cut $(d)$, with a pit at the head reaching a depth of 16 feet. Another shaft $(e), 100$ feet farther west, was 20 feet deep and still being sunk in August, 1918. A shallow prospecting ditch ( $f$ ) was cut across the foliation of the dunite 50 feet farther west. Several shallow pits and numerous small holes made with posthole

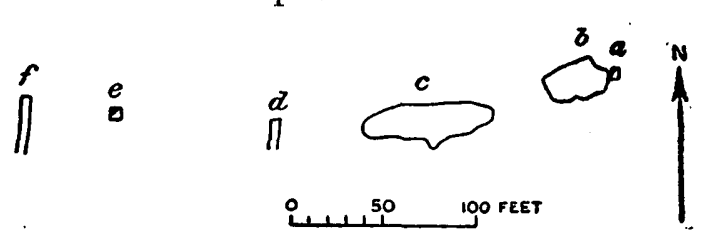

Fraure 26.-Plan of Caroliua Chrome Co.'s workings at Webster, N. C. See text for explanation. digger and auger were sunk in the immediate vicinity before mining operations were begun.

This is the only recent attempt to mine chrome ore in the Webster district, although the adjoining property of the Consolidated Nickel Co. was prospected in 1918. Earlier workings went little beyond the prospecting stage, although several tons of ore is said to have been taken from some of the cuts and shallow pits, and some shipments are known to have been made about 30 years ago.

Character of the ores.-The "vein" at the Carolina Chrome Co.'s mine is essentially vertical and $2 \frac{1}{2}$ feet thick at shaft $a$ and open cut $b$ (fig. 26). It consists of thinly laminated chromite and dunite, but the proportion of chromite becomes less toward the inner (southern) limit of the ore. Thus it is not a true vein but a vertical sheet of foliated dunite containing partly segregated ore and in places tabular masses and lenses of solid chromite. Running through both massive and banded ore are films and stringers of dense scaly kämmererite, which in places forms veins 2 inches or more in thickness. Rarely broad flakes exceeding an inch in diameter are found, and in places minute pseudohexagonal crystals are recognizable. A little talc and chlorite and minor amounts of green nickel stain are common.

The inclosing foliated dunite is decomposed in the main shaft and the open cuts to a soft yellowish-brown mass, which is very porous from the great loss of soluble products during the process of decay. Consequently it holds an astonishing amount of water, which squirts out copiously at every stroke of the pick, whence the miner's local name "eye-water rock." 
Lying nearly flat and therefore directly across the foliation in this decomposed rock are many seams of massive and honeycombed white chalcedony, commonly not more than 3 or 4 inches thick but in some places attaining a thickness of 10 inches. These are crossed by many smaller nearly vertical veinlets of the same character-all in contrast with the brown color of the lateritic dunite. The ore passes downward through the horizontal sheets of chalcedony without change except for the complete replacement of the original olivine by chalcedony, the chromite remaining unaffected and retaining its original distribution.

The chromite content of the ore was found to vary both vertically and horizontally, the workable portions taking the form of ill-defined shoots pitching westward. The first shoot mined extended westward from the main shaft and was worked out in open cut $b$, except a pillar at the shaft; beyond it about 50 feet of nearly barren rock. The second shoot was mined out chiefly in the east end of cut $c$, and 25 feet west of the middle the chromite content fell off seriously. The dip of the foliation in the west end of cut $c$ becomes $50^{\circ} \mathrm{N}$., which is abnormal for this locality. The cut and pit 50 feet farther west $(d)$ show the same conditions as at the west end of open cut $c$, with 10 feet of vertically laminated dunite interspersed with stringers of ore, the whole said to average about 10 per cent chromite. At the time of the writer's visit shaft $e$ was just coming into a lens of massive ore at the depth of 20 feet and showed also a considerable amount of banded disseminated ore. Here the dunite contains veins of white to pale-purplish magnesite, 2 to 3 inches thick and having broad rhombohedral cleavage surfaces.

Most of the ore mined here was taken from the surface concentration in residual soil and from the soft disintegrated dunite beneath. The increasing firmness of the rock in depth and the thinner cover of disintegrated material in the more westerly workings made mining more difficult and expensive, and in order to offset increasing costs attention was concentrated more and more upon the richer bodies of ore. On the other hand, a considerable area of soil in the immediate vicinity of the mine is said to have shown an attractive percentage of chromite for sluicing operations.

The Consolidated Nickel Co. owns the greater part of the peridotite area about Webster, and work was done on its property at localities 2, 3, and 4 (fig. 25) in prospecting for chrome ore in 1918. Cut 2 is about 800 feet southeast of the Carolina Chrome Co.'s shaft (1) and 150 feet lower on the eastern slope of the ridge, toward the river. The cut is in dunite near thetsouthern contact with the gneiss, though just how near is not definitely determinable. It is 40 feet long, 3 to 5 feet wide, and has a maximum depth of 18 feet. From 8 to 10 tons of ore, consisting of chromite intimately mixed with fine 
scaly talc and chlorite, was taken out. A small body of ore 18 inches thick, apparently a remnant of a lens, shows at the west end of the cut.

Cut 3 is an old working reopened 1 mile west by south from cut 2, at the tip of the elbow in the peridotite outcrop. Several tons of ore is said to have been taken from this place some 30 years ago. The cut crosses the contact and extends about 40 feet into the dunite, which is here full of slippery talc and chlorite seams. The ore forms an irregular tabular mass approximately vertical and extending nearly due east. It has a maximum thickness of 1 foot, but there are smaller parallel veins in the dunite, which is soft and friable from decomposition to a depth of about 15 feet, almost the maximum depth of the cut. Ore roughly estimated at 2 tons, with a gangue of fine scaly talc and olivine, was recovered from the slight deepening and widening of the old cut.

An old pit 18 feet deep was opened at locality 4 (fig. 25), on the western contact of the dunite about 1,000 feet south of Tuckasegee River, also a trench 25 feet long, 8 feet deep, and 4 feet wide in the talc schist of the contact. This opening extended somewhat beyond the older workings and yielded about three-fourths of a ton of ore, in masses ranging from less than 1 pound to about 50 pounds each-all coated and intricately veined and in part intimately mixed with talc. The chromite is pitch-black and has a brilliant glossy luster on the fresh fracture.

The cut at locality 5 (fig. 25) is on the southeast slope of the hill 500 feet from the main street of Webster and 60 feet lower, at the north side of the old Tuckasegee road. The location, in the middle of the dunite area, is quite exceptional. The old pit was dug in the search for chromite many years ago and has recently been reopened. It now shows only two nearly vertical north-south stringers of ore about 3 feet apart and ranging in thickness from 1 to 3 inches. The ore consists of granular chromite and fine scaly talc and kämmererite in compact aggregates. It is said that a pocket of ore that pinched to a small stringer at a depth of 9 feet was mined when the pit was first opened, and several tons of ore was obtained for shipment. Remnants of the old ore were obviously taken from thicker masses than any now exposed in the pit.

Along the western contact of the dunite, in the vicinity of locality 6 (fig. 25), about a quarter of a mile north of Webster, many blocks of float chrome have been found on the slopes of the hill and along the small brook on the lands of O. B. Coward, J. L. Broyles, and Taylor Buchanan. A ditch recently dug for other purposes encountered similar blocks in the soil. No prospecting has been done, and the few scattered outcrops show no ore in place. 
Ores at Soapstone Gap.-At the head of Cane Creek, 5 miles northeast of Webster, begins a series of narrow peridotite outcrops which passes northeastward through Soapstone Gap into the drainage basin of Scotts Creek. At the gap, as the name suggests, there is much talc, and recent prospecting has disclosed the presence of small lenses and scattered nodules of chromite, although not enough was found to encourage the undertaking of mining operations.

Ores near Balsam.-On Dark Ridge Creek, 8 miles northeast of Webster and 2 miles southwest of Balsam, an oval mass of peridotite underlies an area 800 feet wide and about 2,500 feet long. The creek cuts across it near its southwest end and the railroad traverses it near the northeast end. The peridotite is coarse grained and ranges from dunite to harzburgite. Individual olivine grains show cleavage surfaces in some places as much as 6 inches across, although such grains are invariably much broken by irregular cracks and hence have the appearance of a granular rock of medium texture. Small fragments of float chromite are found near the north contact, and about 250 feet from the southern border some disseminated ore appears in outcropping ledges of granular yellowish-green dunite, accompanied by small lenses and irregular stringers of ore with a maximum thickness of 3 inches. An old cut opened here many years ago is said to have yielded 15 tons of shipping ore having an average content of 49 per cent of chromic oxide.

About 1 mile south of Balsam and 9 miles northeast of Webster in a direct line chrome ore has been found in a series of dunite outcrops with much schistose talc and chlorite. In the summer of 1918 pits, shallow shafts, and several cuts and prospecting trenches were opened here, in and near a small mountain gap at an elevation of about 3,800 feet above sea level. Many small lenses and irregular lumps and stringers of ore were encountered, but no considerable deposit was found.

The deepest shaft was sunk beside a small talcose peridotite outcrop in the gap. Mr. G. W. Wertz, who was in charge of the work, reports that at a depth of 35 feet the peridotite was bottomed. The shaft was sunk to a depth of 45 feet without finding any more of the rock, and a crosscut was driven in the decomposed gneiss beneath the peridotite. The bottom of the peridotite was found to be "smooth like it had moved." This is the universal condition of the peridotites along which movement has occurred since their intrusion. This experience indicates that a definite limit in depth of the ore deposits may be found in other places.

Half a mile west of the small gap the outcrop broadens to more than 100 feet where it is crossed by a small stream, and here harzburgite constitutes the greater part of the mass, with subordinate 
amounts of dunite. Talc is abundant near the southern contact, and small lumps of float ore occur, but no prospecting has been done at this place.

\section{DEPOSITS AT DEMOCRAT AND VICINITY.}

Geography.-Democrat is on Ivy River at the northern border of Buncombe County, 14 miles north of Asheville. The dunite with which the ores of this district are associated extends from Morgan Hill, $1 \frac{1}{2}$ miles southwest of Democrat, for $3 \frac{1}{2}$ miles N. $30^{\circ}$ E., reaching a mile into the southeast corner of Madison County. About the middle of this course there is a gap of nearly half a mile at the river, half a mile below (west of) Democrat, where the peridotite fails. The line of outcrops traverses a hilly region along which the maximum relief is not over 400 feet, but the immediately adjacent ridges and knobs rise 1,600 feet above the river, and several peaks of the Great Craggy Mountains, of which these are spurs, rise 2,300 to 2,400 feet higher still, attaining elevations above 6,000 feet. The mountain slopes are covered with forests, and Ivy River, which drains the west slope of these mountains and flows westward into the French Broad, furnishes an abundance of water and power for mining and milling operations.

Geology.-The dunite south of Ivy River gradually broadens northward to a maximum width of about 1,100 feet at the Carolina Chrome Co.'s mine, near the river. North of the river also the narrow line of dunite outcrops widens to 1,800 feet beyond the Madison County line, forming a blunt lenticular mass on Holcombe Branch, which flows westward into West Fork $2 \frac{1}{2}$ miles above its junction with Ivy River. The broadest parts of both dunite areas are partly barren of vegetation, although they are subject to the creep of soil from the gneisses on adjacent slopes. The southern outcrop is in the hornblendic Roan gneiss; that north of the river lies along the contact of the Roan gneiss at the west and the micaceous Carolina gneiss at the east. Most of the dunite in both areas is distinctly foliated, like that at Webster. Chromite grains are scattered abundantly through the rock, and green nickel stains are common in the joints. Boulders and smaller lumps of float chrome ore are also rather common.

From half to three-quarters of a mile north of the river several small isolated masses of dunite, are exposed in the banks of a deep gully at the roadside. Some of these are only about 6 inches in diameter and are surrounded by a sheath of radial talc about an inch thick; outside of this is a layer of schistose brown vermiculite, reproducing on a small scale the characteristics of the large peridotite intrusive bodies. One of these small masses about a foot thick breaks across the foliation planes of the inclosing gneiss, although 
most of them lie conformably with the foliation, as do most of the large masses. A similar isolated mass several feet in diameter and almost circular in cross section is exposed in a cut along the new road about a mile southwest of Democrat.

Pegmatite crops out prominently at several places about the gneiss and peridotite contacts, and a pegmatite dike intersects the dunite at Morgan Hill. The old Carter corundum mine was in the midst of the broad dunite outcrop in Madison County $1 \frac{1}{2}$ miles north of the river. It was operated in the middle eighties on a deposit of cleavable pink and white corundum which is intimately associated with massive greenish-black spinel, coarse cleavable white albite, chlorite, and vermiculite. Large amounts of talc have been formed, especially about the thinner portions of the dunite, and lumps of dense brownish chalcedony are common in many places on the surface.

Many pits and shallow cuts and several shafts, some of which are said to have been 50 to 60 feet deep, were opened in connection with mining and prospecting for corundum and prospecting for nickel. The search for nickel was also active in the dunite area south of the river.

Ore deposits and mining.-A carload of chrome ore, partly mined from pockets and partly gathered from the surface at Morgan Hill, $1 \frac{1}{2}$ miles southwest of Democrat, is said to have been shipped from Asheville some years ago. No other earlier work for chromite is known to have been done in this district. In October, 1917, S. H. Hamilton began prospecting the property which he later mined for the Carolina Chrome Co., on the south side of Ivy River half a mile west of Democrat. Legal complications concerning ownership of mineral rights took nearly seven months to untangle. Work was begun about May 1, 1918, by constructing an experimental flume 1,000 feet long for washing residual chromite-bearing soil, the water for which was pumped from the river. With the addition of a classifier operations were continued by this simple method until August. A concentrating table was then installed and used until the end of the war stopped the work. Concentrate estimated at 30 to 40 tons was produced but not shipped. This ore is remarkable, possibly unique, in the fact that it consists chiefly of perfect octahedral crystals of chromite. It is said to contain more than 55 per cent of chromic oxide and very little silica.

The ground was sampled by means of trenches and the use of a posthole digger. Samples of 1 kilogram each were taken, and the chromite content was determined by panning and weighing the concentrate, which gave results reported to have ranged from 1.5 to 8.5 per cent of chromite, with an average of about 3.5 per cent. Nearly a million cubic yards of washable ground was covered by the sam- 
pling, and a larger area in which the conditions seem to be the same awaits exploration.

The ore obtained from this place was produced entirely from washing the surface soil, but this work uncovered small lenses and a considerable showing of disseminated ore in the dunite beneath. Similar chromite-bearing soil occurs in the dunite area on Holcombe Branch, $1 \frac{1}{2}$ miles north of Democrat, but as it has not been sampled its chromite content is not known. The small pockets and thin layers of natural concentrate in the sand of gullies and streams at the two places are similar in every respect.

Lenses of massive ore and lumps of float occur at Morgan Hill, $1 \frac{1}{2}$ miles southwest of Democrat. A cut about 40 feet long was opened in the peridotite near its western border and also very near its southern extremity. The fine-grained yellowish-green dunite contains scattered grains of accessory chromite and also veinlike segregations of chromite intimately intergrown with dense scaly talc and ranging from 1 inch to 2 feet in thickness. The south end of the cut is in a pegmatite dike, which here intersects the dunite.

\section{DEPOSITS ABOUT BURNSVILLE.}

Geography.-Chrome-ore deposits have attracted attention at Price Creek, $5 \frac{1}{2}$ miles southwest of Burnsville, and at the Ray mine, at Mine Hill, on Mine Fork of Jacks Creek, $3 \frac{1}{2}$ miles north of Burnsville, both distances measured in a direct line. At the peridotite outcrops the relief is only 200 to 300 feet, up rather steep slopes from the creeks; but the mountains in the immediate vicinity rise 2,000 to 2,500 feet higher. The Price Creek locality is 8 miles by a good dirt road from Burnsville, the nearest shipping point. The Ray mine is 4 miles by road from Burnsville, but Green Mountain, a station on the Carolina, Clinchfield \& Ohio Railroad, is only 3 miles north, over a fair mountain road of moderate grades.

Geology and ore deposits.-At Price Creek the ore was found with a small north-south lens of dunite whose outcrop was less than 100 feet wide and between 300 and 400 feet long, in decomposed hornblendic Roan gneiss. Talc and radial anthophyllite are prominent. Outcrops are few, and no ore is now visible in place. Two old tunnels and an open cut, now badly caved, were opened here for chrome ore more than 25 yeare ago. A pocket of ore is said to have yielded 7 tons, which was shipped. Remnants of an ore pile show small lumps, stringers, and some disseminated ore with veinlike segregations 2 inches thick. 
Analyses of chrome ore from Price Creek, Yancey County, N. C.

\begin{tabular}{|c|c|c|}
\hline & 1 & 2 \\
\hline 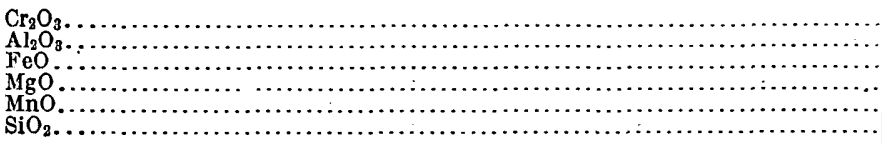 & \begin{tabular}{r|}
59.20 \\
7.15 \\
25.02 \\
4.42 \\
.92 \\
3.20
\end{tabular} & 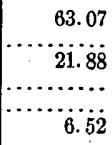 \\
\hline $\mathrm{Cr}: \mathrm{Fe}$ (atomic ratios) $\ldots \ldots \ldots \ldots \ldots \ldots \ldots$ & $\begin{array}{r}99.91 \\
2.24: 1\end{array}$ & $\begin{array}{r}91.47 \\
2.73: 1\end{array}$ \\
\hline
\end{tabular}

1. Aualysis by Charles Baskerville, North Carolina Geol. Survey, vol. 1, p. 373, 1905.

2. Analysis by H. B. C. Nitze, North Carolina Geol. Survey Bull. 1, p. 214, 1893.

Ray mine.-The peridotite area at the Ray mine contains both dunite and harzburgite and has the usual lenticular outline. The outcrop is about half a mile long and 1,000 feet wide, with the long axis lying N. $30^{\circ} \mathrm{E}$. It tapers to a point at the south but is blunter and more rounded at the north. Chromite grains are rather abundant throughout the rock. Part of the western contact is followed by a pegmatite dike 20 feet thick. A quartz vein 4 feet thick and traceable for 100 feet within the peridotite is also doubtless pegmatitic in origin. Mine Fork, flowing north into Jacks Creek, cuts diagonally across the peridotite outcrop near the middle, leaving a peridotite hill about 100 feet high to the southwest and a larger one, about 200 feet high, to the northeast.

In both the earlier and the recent workings chrome ore was mined near the top of each of these hills in open cuts and pits. In the recent work an open cut near the north end of the outcrop also produced ore. In the more southerly openings the veinlike stringers run nearly due east. In the cut about 40 feet long west of the road these stringers are very irregular and discontinuous. They are both more uniform and more continuous in the cut and shaft on top of the hill east of the creek. At the time of the examination (August, 1918) this shaft had reached a depth of 20 feet and the work was still in progress. The strike of the well-defined "vein" here is east, and the $\operatorname{dip} 61^{\circ} \mathrm{N}$. In thickness it ranges from an inch near the surface to 17 inches in places at a depth of 20 feet. In a trench extending 10 feet east and about 40 feet west from the shaft and ranging in depth from 6 to 10 feet the vein nowhere exceeds 3 inches in thickness.

In the cut near the northeast end of the peridotite the ore bodies extend irregularly northeast. Small pockets of ore were found in a number of prospecting pits, cuts, and trenches. It is estimated that about 40 tons of ore, partly cobbed and ready for shipment, was left on the ground at the close of operations soon after the signing of the armistice.

$98707^{\circ}-22-10$ 
Analyses of chrome ore from the Ray mine, Yancey County, N. C.

\begin{tabular}{|c|c|c|}
\hline & 1 & 2 \\
\hline 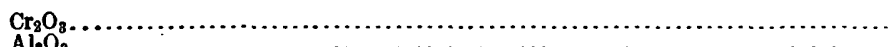 & 49.87 & $\begin{array}{l}58.00 \\
15,52\end{array}$ \\
\hline 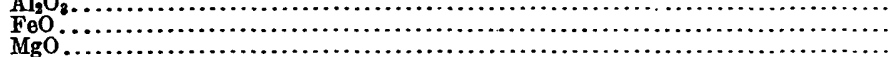 & 24.26 & $\begin{array}{r}14.45 \\
8.26\end{array}$ \\
\hline $\begin{array}{l}\mathrm{C} \\
\mathrm{SiO}_{2}\end{array}$ & 13.00 & 3.20 \\
\hline 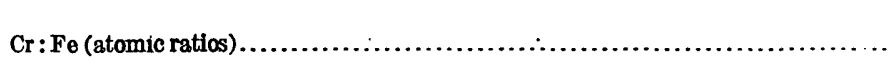 & $\begin{array}{r}87.13 \\
2.06: 1\end{array}$ & $\begin{array}{l}100.13 \\
3.80: 1\end{array}$ \\
\hline
\end{tabular}

1. Analysis by H. B. C. Nitze, North Carolina Geol. Survey Bull. 1, p. 213, 1893.

2. Analysis by Charles Baskerville, North Carolina Geol. Survey, vol. 1, p. 382, 1905.

\section{ORIGIN OF THE CHROME ORES.}

\section{OCCURRENCE AND DISTRIBUTION.}

The lenses, pockets, and other masses of chrome ore and also the disseminated or partly segregated ore occur chiefly in the outer portions of intrusive masses of peridotite or its alteration products near the contact with the inclosing gneiss. They do not form veins in the proper sense of that term, and in most places there are no well-defined walls. The gangue minerals, like the chromite itself, are the normal constituents of the rock, and gradations into the peridotite are of common occurrence. Where distinct veinlike walls occur, with a clearly defined separation between ore and rock, the planes of division commonly coincide with the foliation, and in most places this is the more obvious because of the development of schistose talc and chlorite about the lenticular or tabular ore bodies.

Some of the lenses and pockets of ore are connected in series by thin sheets or stringers through the intervening barren rock, but most of them are independent isolated masses. These masses are commonly associated, however, in various ways-for example, they crop out in a line or in some parallel arrangement, as side by side or overlapping or steplike (en échelon). Bodies of rock that are thickly set with grains and crystals of chromite, constituting the disseminated ore, are commonly associated with lenses, pockets, and stringers of massive ore. As a rule, such disseminated ore is much streaked by alternating bands of rich and lean rock, and generally it includes stringers and small lenses of massive ore in every respect like the larger bodies. Gradual transitions from this type to normal peridotite are also common, although sharp contrasts are seen in many of the more highly foliated rocks.

Whether these two types of primary ore occur together or independently, they are almost invariably near the gneiss and peridotite contact, and the chromite decreases within a short distance to the status of a minor accessory somewhat evenly scattered through the rock. In some outcrops of peridotite where no chrome ore has been 
found it has been observed that chromite as an accessory mineral is notably more abundant near the contacts.

\section{THEORY OF MAGMATIC SEGREGATION.}

The facts of occurrence and distribution of chromite set forth above are all in accord with the theory of magmatic segregation, which accounts for the origin of these ores by the free movement of chromite grains in a liquid magma, the massive ores differing from the disseminated ores only in the degree of completeness of the segregation. The mechanics of the process is conceived to be primarily gravitational. The continuous loss of heat to the cold inclosing rock after the intrusion of the liquid peridotite magma, by increasing the density of the outer parts of the liquid and by partial crystallization, which still further increased the "aggregate specific gravity," caused these parts to move downward along the contacts to the bottom of the reservoir. The hotter and therefore lighter interior parts of the liquid were thus steadily forced upward, and eventually all parts of the magma were repeatedly carried down the side walls. Meanwhile the crystallization of chromite was taking place chiefly in these cool outer parts of the magma, and much of this mineral was lodged in the thickening walls of olivine formed by gradual solidification of the liquid at the contacts. The flattened tabular and lenticular forms of ore and the parallel banded structure in most of the disseminated bodies may be attributed to this convectional circulation. ${ }^{28}$ Such parts of these accumulations as broke away from the cooling sides might be caught in any portion of the interior when movement finally ceased, and this may account for the exceptional occurrence of chrome ore in the midst of the peridotite mass.

\section{SUPPOSED DEEPER-SEATED ORES.}

It has sometimes been supposed that much of the chromite was carried down to the bottom of the intrusion and that such accumulations may have been further increased by the gravitational settling out of crystals from the central parts of the magma when these parts had cooled sufficiently for the mineral to crystallize there. Accordingly large bodies of ore have been supposed to exist in the deeper parts of the peridotite masses, at depths perhaps too great in many places to be mined. The uncertainty of this supposition, however, can not be too strongly emphasized. Some of the most important factors involved are entirely unknown. In the first place, the rate of movement in the convectional circulation of a magma is entirely conjectural. If it were sufficiently rapid the tendency of chromite

${ }^{2}$ For a discussion of rhythmic banding see Grout, F. F., Two-phase convection in Igneous magmas; Jour. Geology, vol. 26, pp. 481-499, 1918. 
grains to settle through the central parts would be overcome, and the crystals would be swept upward instead, to be in turn carried down along the cooling walls. This movement might also send upward through the central magma such crystals as reached the bottom through the downward convection along the sides, and some of them might traverse the circuit repeatedly before coming to rest. Cooling and solidification at the bottom would be negligible compared with that at the top and sides; hence there would be no trap to catch such particles of chromite as failed to lodge on the sides.

The degree of viscosity. of such a magma is also unknown, but with chromite grains below 2 millimeters (one-twelfth of an inch) in diameter, as most of them are, a very slight viscosity in the heavy liquid would so greatly retard their settling that a very gentle upward current would serve to reverse the movement. Increasing viscosity and the crowding of crystalline grains as the central parts of the magma finally approached the solidifying point would gradually retard all gravitational movement, and there might be no opportunity at any stage of the process for concentration at the bottom.

Other considerations may also shed some light upon the question of the existence of such supposed deeper-seated ores. The Appalachian peridotite belt, from central Alabama to Newfoundland, is more than 2,000 miles long. About 200 miles of this distance is included in that part of the belt that lies diagonally across western North Carolina, and in this region alone hundreds of isolated masses of these rocks have been examined and mapped. The greatest dimensions of some of these outcrops are expressed in miles; diminutive bodies at the other extreme are less than a foot across. The smallest may be assumed to belong to apophyses from larger neighboring masses which may or may not appear at the surface, and it is not unreasonable to suppose that many of the outcrops with dimensions of, say, a few hundred feet or less may broaden out as continued erosion exposes the greater bodies of rock beneath. On the other hand, it is equally reasonable to suppose that others have passed that stage and that some are even now but the dwindling remnants of larger masses that were long ago removed by erosion. The bottoming of a small peridotite mass only 35 feet below the outcrop at Balsam seems to furnish an example of this class. Except where the feeding dikes or necks rise from the deep-seated source of the magma, such remnants must eventually disappear with the continued lowering of the surface.

In short, some of the hundreds of peridotite masses along this portion of the great Applachian belt probably stood at different levels within the earth at the time of their intrusion as liquid magma and their subsequent cooling and crystallization, and the present land surface doubtless cuts some of them near their summits, others through the middle, and still others near their lower limits. There- 
fore such deeper-seated bodies of ore, if they really exist, might reasonably be expected to crop out here and there. No such deposits have been found in these 200 miles, or in the 2,000 miles of the whole Appalachian belt, nor in the present state of knowledge is their discovery in the future very confidently expected. ${ }^{29}$

\section{PROSPECTING FOR CHROME ORE.}

Boulders and smaller lumps of float ore furnish the most obvious and the most common guide to the prospector in this region. Such ore is found about the peridotite outcrops or on the slopes below them in many places. This float is traced up the slope as far as surface fragments can be found, and the borders of the peridotite are searched for possible outcrops of lenses or stringers of ore. Crosscutting trenches are useful where the ore is still being sought, and longitudinal trenches where ore that has been found in outcrop or in a pit or crosscutting trench is followed along the strike. Enlargements into workable pockets or lenses may thus be located, and stringers from one such body of ore may be found to lead along the strike to another.

Prospecting in the larger barren peridotite areas is very simple. There is little soil, and outcrops of the rock are numerous. Both soil and vegetation, however, are commonly more abundant about the borders, where the prospector concentrates his attention. Moreover, some of the outcrops are so situated that soil creep from higher ground traverses the whole area and the contact is not easily found. In such places a few shallow pits will generally locate it approximately, and crosscutting trenches can then be run inward from the border at intervals.

In connection with the recent revival of chrome-ore mining in this region, sands along some of the streams were examined by panning, and larger samples were tested on a concentrating table, but workable deposits were not found. On the other hand, chromite grains partly concentrated in gullies and along roadsides and mingled in residual soil were successfully used as guides in the search for workable deposits of disseminated ore. The mill at Webster was located on productive deposits by this method. Chromite found in the sand was traced up the hill by examining ant hills and by searching the surface of the ground with a reading glass. The most promising looking ground was then sampled at regular intervals by means of a posthole digger and a clay auger. The soil samples thus taken

20 "A study of the igneous rocks shows that specific gravity plays no important role in the arrangement of the constituents, even in the case of the heavier ores, great masses of llmenite, magnetite, and chromite, and presumably also of platinum occurring in schlieren-like segregations and not at the base of the igneous body with which they are associated."-Weinschenk, E., The fundamental principles of petrology, translated by A. Johánnsen, p. 45, New York, McGraw-Hill Book Co., 1916. 
were weighed and panned, and their chromite content was determined by weighing the concentrate. On the basis of this sampling crosscutting trenches were dug at 50-foot intervals and extended up the slope as far as the soil continued to show chromite. Cuts and pits were opened along these trenches wherever ore was found in the underlying rock, and the best of these openings were developed into the mine workings.

A word of caution may be repeated here concerning the significance of float ore and residual chromite-bearing soil. Both of these types of secondary ore have come from the crumbling and washing away of the inclosing rocks for long periods of time, and in places there has been considerable concentration. Hence boulders and lumps of float ore, even where they are numerous, are not a sure indication of profitable ore bodies in the underlying rock; nor does the rich chromite-bearing soil necessarily point to a similar richness of disseminated or spotted ore beneath. However, both float and soil are the best guides, next to natural outcrops of ore in place, and a certain amount of original ore may reasonably be expected to supplement the secondary.

The prospector should bear in mind the fact that owing to its variable composition some chromite is magnetic, grains and small lumps of it being readily picked up by the ordinary pocket magnet or a magnetized knife blade. Such magnetic varieties may well come within the range of commercially valuable ores. On the other hand a nonmagnetic black spinel might appear to be a good chrome ore, although it contains so little chromic oxide as to be worthless. Fortunately for the prospector, there are few localities in the North Carolina chromite region where such a spinel occurs in any notable quantity.

In view of the facts just noted, however, and of the further fact that the commercial value of a chrome ore is determined primarily by its chemical composition, it is of the highest importance that field observations be checked by analyses, as urged by Singewald, ${ }^{30}$ particularly wherever they are likely to become the basis of mining operations.

\section{CONCLUSIONS.}

1. No large bodies of chrome ore have been discovered in North Carolina, and as the pockets are commonly mined out as fast as they are found, there are practically no ore reserves of the massive type in sight. Continued discovery of scattered masses may be expected if systematic search is made for them, but no dependence can be placed upon their continuity beyond the limits of the explored ground.

${ }^{30}$ Singewald, J. T., Jr., Econ. Geology, vol. 14, p. 197, 1919. 
2. Under normal market conditions only a small and irregular production of chromite, if any, can be expected from North Carolina, particularly if mining operations are confined to pockets of massive ore, to the neglect of other sources.

3. In periods of emergency the chromite production of this region can readily be brought up to a few hundred tons a year, and the deposits are valuable as reserves to be drawn upon when imported ores are not procurable.

4. From 1,000 to 2,000 tons of high-grade concentrates are indicated as available in a small area of residual ore at the Democrat mine, according to reported results of tests. Other areas of similar ground remain untested.

5. The commercial recovery of such residual ores in several localities is thought to be feasible if a simple, inexpensive, perhaps semiportable concentrating plant can be adapted to the work. With the addition of appropriate crushing machinery the same plant could be used for concentrating the disseminated ores.

6. The close association of massive and disseminated ores and in some localities residual deposits as well makes possible their exploitation together in a series of small mines, with proper equipment and management.

7. No valuable alluvial or stream deposits of chromite have been found in North Carolina, and in view of the swiftness of the mountain streams, it seems likely that no workable deposit will be discovered. 
